\author{
Contato \\ Av. Ph Rolphs s/n - Centro \\ 36570-000 - Viçosa - Minas Gerais - Brasil \\ E-mail: rubenspanegassi@gmail.com
}

\section{OS ARTIFÍCIOS DA PERFEIÇÃO: JOÃO DE BARROS POR MANUEL SEVERIM DE FARIA*}

\section{Rubens Leonardo Panegassi"}

Universidade Federal de Viçosa

\title{
Resumo
}

O objetivo deste artigo é problematizar as convenções intelectuais que nortearam a escrita do retrato heróico do humanista João de Barros por Manuel Severim de Faria, em sua "Vida de João de Barros, em que se discorre sobre os preceitos da história e perfeição com que escreveu as suas Décadas", livro que compõe os Discursos vários políticos, publicado pela primeira vez em 1624. Para isso, consideramos que a confecção da memória dos lugares ocupados por João de Barros responde à demanda de uma sociedade estamental, na qual a dignidade do ofício exercido denota a dignidade de quem o exerce.

\section{Palavras-chave}

Portugal - Severim de Faria - João de Barros - corte.

* Este texto, acrescido de modificações, se desdobra de nossa tese de doutorado $O$ pasto dos brutos: contexto de João de Barros, "horizonte histórico" e política nas Décadas da Ásia, defendida no Departamento de História da Universidade de São Paulo - FFLCH/USP, em 2013, e que contou com o financiamento da Fundação de Amparo à Pesquisa do Estado de São Paulo (Fapesp) - processo $n^{\circ}$ 09/54376-6. Vale a ressalva de que "as opiniões, hipóteses e conclusões ou recomendações expressas neste material são de responsabilidade do autor e não necessariamente refletem a visão da Fapesp". Agradeço às observações dos pareceristas ad hoc da Revista de História, bem como a preciosa ajuda de Ana Paula Torres Megiani e José Carlos Vilardaga

** O autor é doutor em História pelo Departamento de História da Faculdade de Filosofia, Letras e Ciências Humanas da Universidade de São Paulo, professor de História Moderna e Contemporânea no Departamento de História do Centro de Ciências Humanas, Letras e Artes. 
rev. hist. (São Paulo), n. 171, p. 175-212, jul.-dez., 2014 http://dx.doi.org/10.11606/issn.2316-9141.rh.2014.89011

\title{
THE ARTIFICES OF PERFECTION: JOÃO DE BARROS BY MANUEL SEVERIM DE FARIA
}

Contact Av. Ph Rolphs s/n - Centro 36570-000 - Viçosa - Minas Gerais - Brasil E-mail: rubenspanegassi@gmail.com

\section{Rubens Leonardo Panegassi}

Universidade Federal de Viçosa

\begin{abstract}
The purpose of this article is to discuss the intellectual conventions that guided the writing of the heroic portrait of the humanist João de Barros by Manuel Severim de Faria, in his "Vida de João de Barros, em que se discorre sobre os preceitos da história e perfeição com que escreveu as suas Décadas", book that integrates his Discursos vários políticos, published in 1624. For this, we consider that the invention of the João de Barros trajectory responds to the demand of an estamental society in which the dignity of the exercised office denotes the dignity of those who exercise the office.
\end{abstract}

\section{Keywords}

Portugal - Severim de Faria - João de Barros - court. 
A ausência do rei e sua corte é um fenômeno marcante do século XVII português. Em vista disso, as celebrações do passado podem ser compreendidas como uma das respostas frente à situação de crise política que acompanhou o processo de legitimação de Filipe II em Portugal. Todavia, a produção literária destinada a selecionar e impor sentidos ao passado português deve ser observada, também, à luz da lógica de uma sociedade estamental, em que o uso da escrita assegura distinção social e pode garantir espaço junto ao rei e seus benefícios.

Manuel Severim de Faria faz parte de uma geração de letrados que vivenciou este contexto. Problematizar a confecção dos lugares ocupados por João de Barros no retrato heróico composto por Severim de Faria em sua "Vida de João de Barros, em que se discorre sobre os preceitos da história e perfeição com que escreveu as suas Décadas" é o interesse deste artigo. Em vista disso, atentamos para a figura do humanista no seio de uma cultura construída sob o signo da imitação, em que a produção da memória do cortesão remete-nos a um ambiente no qual a dignidade de cada um define-se, também, pela dignidade de seu ofício.

\section{A Vida de Manuel Severim de Faria}

Em seus Discursos vários políticos, ${ }^{1}$ publicados em Évora no ano de 1624, Manuel Severim de Faria, além de se debruçar sobre temas como a importância do aumento da Monarquia espanhola, a passagem da residência de Filipe II a Lisboa, a perfeição da língua portuguesa, as condições para o exercício da caça e de compor uma história da indumentária eclesiástica em Portugal, escreveu, também, a biografia de alguns dos mais notáveis autores portugueses, dentre os quais, Luís de Camões, Diogo do Couto e o antecessor de ambos, João de Barros. ${ }^{2}$ Da obra de Severim de Faria é possível afirmar que inúmeros de seus manuscritos foram reduzidos às cinzas pelo incêndio subsequente ao terremoto de 1755, por isso, a maior parte do que hoje se conhece foi publicado quando o autor era vivo. De seus Discursos, além da edição de Manuel Carvalho, de 1624, há uma segunda edição, de 1791, feita

1 FARIA, Manuel Severim de. Discursos varios politicos, por Manoel Severim de Faria Chantre, É cônego na Santa Se de Evora. Evora: impressos por Manoel Carvalho, impressor da Universidade, 1624.

2 Cf. FARIA, Manuel Severim de, op. cit. Cf. também SARAIVA, António José \& LOPES, Óscar. História da literatura portuguesa. Porto: Porto Editora, 2008, p. 287. 
rev. hist. (São Paulo), n. 171, p. 175-212, jul.-dez., 2014 http://dx.doi.org/10.11606/issn.2316-9141.rh.2014.89011
Rubens Leonardo Panegassi

Os artifícicos da perfeiç̃ão: João de Barros por Manuel Severim de Faria

por Joaquim Francisco Monteiro de Campos Coelho e Sousa ${ }^{3}$ e, por fim, a edição de 1999 de Maria Leonor Soares Albergaria Vieira. ${ }^{4}$

Por sua vez, é relevante considerar que a leitura dos Discursos deve ser articulada, por um lado, à especificidade de um contexto no qual a Antiguidade é percebida de modo paradigmático, em função da cristalização de um percurso histórico que a compreende como um momento ideal da história da humanidade, ${ }^{5}$ e, por outro, em função de que as práticas de escrita denotam uma ação eficaz e digna de confiança na composição do conhecimento e da memória de feitos, pessoas, sentimentos e afetos. ${ }^{6}$ Diante disso, vale notar que sua utilização ganha espaço em uma circunstância histórica que responde à crise política vivida com a União Ibérica em Lisboa, notavelmente em face da ausência do rei e sua corte, de modo que a invenção de uma tradição e a construção de uma memória impõem-se no âmbito de uma "racionalidade cortês", a partir da estabilização da figura de personagens relevantes e que possam ser recuperados como fonte de exemplo moral aos súditos de todo o reino.

Com efeito, em sua "Vida de João de Barros", um dos livros que compõem os Discursos, Severim de Faria dá início ao relato sobre a vida deste personagem, assinalando o fato de que a República de Atenas, "que entre os antigos foi a primeira que ensinou a honrar com prêmios públicos as virtudes excelentes dos cidadãos", ${ }^{8}$ não discriminava a atividade intelectual em detrimento da atividade militar. Em vista disso, a quantidade de monumentos construídos à memória de seus capitães não era maior que a quantidade de monumentos erguidos à memória de seus escritores. Pelo contrário, eram os últimos ainda mais agalardoados que os primeiros, de modo que "só a

3 Cf. SILVA, Innocencio Francisco da. Diccionario bibliogrphico portuguez. Lisboa: Imprensa Nacional, 1862. s. v. "Manuel Severim de Faria".

4 FARIA, Manuel Severim de. Discursos vários políticos. Editada por Maria Leonor Soares Albergaria Vieira. Lisboa: Imprensa Nacional; Casa da Moeda, 1999.

5 Cf. MARAVALL, José Antonio. Antiguos y modernos. Visión de la historia e idea de progreso hasta el Renacimiento. Madri: Alianza Editorial, 1986, p. 283 e ss.

6 Cf. BOUZA ÁLVAREZ, Fernando. Escribir en la corte. La cultura de la nobleza cortesana y las formas de comunicación en el siglo de oro. In: ZUGASTI, Miguel \& MATA, Carlos (ed.). CONGRESO EL SIGLO DE ORO EN EL NUEVO MILÊNIO. Actas, tomo II. Barañáin (Navarra): Eunsa, 2005, p. 77-99.

7 Cf. ELIAS, Norbert. A sociedade de corte: investigação sobre a sociologia da realeza e da aristocracia de corte. Tradução de Pedro Sussekind. Rio de Janeiro: Zahar, 2001.

8 Daqui por diante remeto-me à seguinte edição: FARIA, Manuel Severim de. Vida de João de Barros por Manuel Severim de Faria e indice geral das quatro décadas da sua Ásia (1624). Nova edição. Lisboa: Na Régia Officina Typografica, 1777-1788, p. III. O português foi atualizado por mim. Todas as transcrições das fontes serão igualmente atualizadas. 
Demetrio Falereo, discípulo de Teofrasto, dedicaram mais de 300 em seu louvor; e muito maior cuidado puseram em escrever as vidas dos seus filósofos e oradores, que as dos príncipes e capitães da mesma república".

Evidentemente, é notório que o texto de Severim de Faria não pode deixar de ser compreendido como resultante de um momento que se concebe como uma época já distante da Antiguidade, um ambiente plenamente inserido no contexto da experiência histórica que, tal como sugeriu José Antonio Maravall, permitiu sua assimilação como uma categoria referente a um período histórico singular, concreto e, sobretudo, paradigmático. Contudo, não obstante o comentário de Severim de Faria referente ao mundo antigo, o autor contemporiza ao tratar das motivações do zelo dispensado pelos atenienses a seus escritores e especula a respeito dos possíveis motivos que os levariam a premiar com maior generosidade "o trabalho da escritura" do que a milícia. Primeiramente, afirma que, enquanto o capitão, para alcançar a glória, não pode prescindir do talento e da determinação de seus soldados, o escritor, em seu empreendimento, não pode se valer "mais que de seu trabalho e valor próprio". ${ }^{10}$ Ou seja, na comparação entre o escritor e o capitão, o primeiro é quem deve levar os louros, pois a guerra, por ser uma atividade coletiva, obscurece os feitos virtuosos do capitão, ao passo que a escritura, sendo uma atividade individual, sublima as virtudes do escritor.

Todavia, para Manuel Severim de Faria, a valorização do trabalho não se resumia, unicamente, a uma variação do modo pelo qual se executava a atividade. Havia, ainda, um critério de valoração intrínseco à finalidade do trabalho. Assim, a milícia, além de ofuscar as virtudes individuais, se ocupa da "conservação de um só príncipe ou governador, que muitas vezes é um tirano da república", à medida que, "na escritura, um só trabalha pela conservação de todos, e faz com ela viver na lembrança dos homens aqueles que pela pátria entregaram liberalmente as vidas, e conservando a memória das coisas passadas, dá regra para acertar nas futuras".11

Desse modo, a partir da sugestão de uma oposição - embora nem sempre efetiva - entre milícia e escrita, Manuel Severim de Faria nos faz pensar que, na República de Atenas, tanto o escritor quanto a escritura estavam a serviço do bem público - a "conservação de todos" - enquanto a atividade militar estava a serviço de interesses particulares - "um só príncipe". Com

9 FARIA, Manuel Severim de, op. cit., p. III.

${ }^{10}$ FARIA, Manuel Severim de, op. cit., p. III e IV.

${ }^{11}$ Idem, ibidem, p. IV. 
rev. hist. (São Paulo), n. 171, p. 175-212, jul.-dez., 2014 http://dx.doi.org/10.11606/issn.2316-9141.rh.2014.89011
Rubens Leonardo Panegassi

Os artifícicos da perfeiç̃ão: João de Barros por Manuel Severim de Faria

isso, desenha uma tópica comum da literatura portuguesa: a antinomia entre armas e letras. Notório representante da maneira barroca de pensar e fazer política em Portugal, este viés desdobrava-se na produção de um "saber histórico" específico em que as armas compunham um dos elementos fundamentais na confecção das narrativas históricas. ${ }^{12}$

Por sua vez, Luís de Sousa Rebelo também nos ajuda a compreender a importância dessa tópica, à medida que recupera sua trajetória no âmbito da história da literatura, não apenas em Portugal, mas também no Ocidente. Segundo ele, a tópica remonta à religião pré-histórica indo-europeia, na qual "o sistema cósmico, religioso e social se hierarquizava numa ordem trinitária de funções: a soberania, (...) a guerra e a fecundidade",13 em que a noção de soberania se apresentava intrinsecamente ligada à dualidade régia, ora mágica e terrificante, ora sábia e justa. "Esta antinomia", explica Sousa Rebelo, foi incorporada pelos "mestres da retórica romana" e, ao longo da história, se recompôs na polarização sapientia e fortitudo, formulação que surgiu para qualificar a conduta dos grandes personagens latinos. ${ }^{14}$

Com efeito, a tópica se difundiu principalmente através da pena de retóricos, tratadistas, panegiristas, oradores fúnebres, bem como de outros autores e conheceu terreno fértil no âmbito da civilização hispano-islâmica, ao passo que veiculava o ideal do monarca ilustrado, personagem efetivamente experimentado nesta sociedade. Entretanto, foi ao longo do Renascimento que "transmuda-se o tópico da sapientia et fortitudo no das armas e das letras" para ganhar definitiva importância na península Ibérica ao longo dos séculos XVI e XVII. Atento ao fenômeno, Rebelo faz notar que, por detrás desta querela ideológica e literária, há uma asserção do direito de cidadania,

(...) concretizado na atuação coletiva dos cidadãos, perante a solução imposta para as grandes questões (...) pelo poder das armas. Ora Cícero, tal como Cipião, simbolizava na vida e nos seus escritos esse ideal cívico, ao passo que César tipificava, no plano existencial, a segunda opção. E quando Cícero vai pleitear perante os juízes de instrução o caso do poeta Aulo Licínio, que requeria a cidadania romana (...), argumenta que esse estrangeiro plenamente a merecia por haver ilustrado as letras. Estas, tão estimadas

\footnotetext{
${ }^{12}$ As armas ou, como sugere Maria Lêda Oliveira, a guerra. Para a historiadora, o outro elemento é o Estado que, por extensão, nos remete às letras quando atentamos para a histórica relação destas com o poder. Cf. OLIVEIRA, Maria Lêda. A história do Brazil de frei Vicente do Salvador: história e política no Império português do século XVII. Rio de Janeiro: Versal; São Paulo: Oderbrecht, 2008.

${ }^{13}$ REBELO, Luis de Sousa. A tradição clássica na literatura portuguesa. Lisboa: Livros Horizonte, 1982, p. 195.

${ }^{14}$ REBELO, Luis de Sousa, op. cit., p. 196.
} 
rev. hist. (São Paulo), n. 171, p. 175-212, jul.-dez., 2014 http://dx.doi.org/10.11606/issn.2316-9141.rh.2014.89011
Rubens Leonardo Panegassi

Os artifícios da perfeição: João de Barros por Manuel Severim de Faria

de Cipião e daqueles que formavam o seu círculo, perpetuavam os grandes feitos, que sem elas se quedariam nas trevas (...). Ademais, continha ainda a literatura um forte ensinamento moral, como bem sabia Alexandre Magno, leitor assíduo de poesia e história no meio das suas campanhas. E se a argumentação cicerônica e os exemplos, que a reforçavam, justificavam a concessão do direito de cidadania a um poeta, que já tão altos serviços prestara, e haveria ainda de prestar à República, pelo uso que em louvor dela fizera da sua arte, tampouco haviam de ser eles jamais esquecidos pelos autores renascentistas. ${ }^{15}$

Todavia, o eco deste fenômeno, embora seja nítido em Portugal, é matizado por Rebelo à medida em que a especificidade do contexto no qual o tópico das "armas e das letras" surge não deve ser generalizável a outros contextos.

Em vista desta observação de Sousa Rebelo, vale anotar, em linhas gerais, o contexto no qual Manuel Severim de Faria escreveu sua "Vida de João de Barros", uma vez que, tendo vivido entre os anos de 1583 e 1655, pertence a uma geração de letrados que, embora tenham conhecido a corte de VilaViçosa em todo seu esplendor intelectual, vivenciou também o drama da ausência de uma corte real - e do rei - em terras portuguesas, bem como as implicações do distanciamento desse importante círculo de sociabilidade. ${ }^{16}$ De todo modo, vale observar que Severim de Faria pode ser considerado um humanista, muito embora já não o seja ao estilo do Renascimento, sobretudo em face da nova concepção relativa à importância do poder dos Estados, e pelo conhecimento oriundo da experiência dos Descobrimentos..$^{17}$

Com efeito, sabe-se que Manuel Severim de Faria foi presbítero, mestre em Artes e alcançou o grau de doutor em Filosofia e Teologia pela Universidade Jesuítica de Évora. Por volta dos vinte e seis anos, foi alçado a cônego e, em seguida, chantre de Évora, cargos herdados de seu tio, Baltasar Faria Severim. Foi poeta e, ao que parece, um diligente antiquário, tendo, por isso, cultivado o gosto pela erudição arqueológica. É tido como polígrafo dotado de intensa curiosidade histórica, cujo amplo leque de interesses abarcava, praticamente, todos os domínios do conhecimento, desde a descrição geo-

${ }^{15}$ Idem, ibidem, cf. p. 196 e 198.

${ }^{16}$ Cf. FRANÇA, Eduardo d'Oliveira. Portugal na época da Restauração. São Paulo: Editora Hucitec, 1997. Cf. também MEGIANI, Ana Paula Torres. $O$ rei ausente: festa e cultura política nas visitas dos Filipes a Portugal (1581 a 1619). São Paulo: Alameda, 2004.

${ }^{17}$ Cf. OLIVEIRA, Maria Lêda, op. cit. Por sua vez, Pierre Chaunu assinala que "o século XVII assegura o triunfo dos Estados (...) O Estado clássico ganha em profundidade o que perde em extensão". CHAUNU, Pierre. A civilização da Europa clássica, vol. I. Tradução de Teresa F. Rodrigues. Lisboa: Editorial Estampa, 1985, p. 37 e 38. 
gráfica dos lugares da pátria até numismática portuguesa, genealogia nobiliária, história das universidades peninsulares, história da organização militar portuguesa ou a história dos cardeais portugueses. ${ }^{18}$ Interesses diversos que, sem dúvida, eram compartilhados por toda uma geração de letrados.

Embora homem de carreira eclesiástica, vale notar que Manuel Severim de Faria tem sido apresentado pela historiografia principalmente como historiador e refinado erudito e que, enquanto colecionador de peças e objetos antigos, chegou a constituir o mais célebre gabinete de curiosidades de todo o reino. Por sua reputação, tornou-se uma referência para fidalgos e clérigos dos quatro cantos do Império português, o que fez dele um interlocutor consciente da necessidade de se articular os diferentes lugares de um mundo colonial cada vez mais ameaçado no contexto da união dos reinos ibéricos sob um mesmo cetro. ${ }^{19}$ Nesse sentido, enquanto historiador, sua obra incorpora elementos inerentes a um horizonte intelectual comum a sua época e sua atmosfera mental.

É em face desta circunstância histórica que Diogo Ramada Curto percebe a existência de uma produção literária destinada à invenção de uma tradição destinada a selecionar e impor sentidos às práticas de escrita, sobretudo diante do fato de que a escrita era norteada por uma cultura política centrada em dádivas e mercês, em que a proteção oferecida não apenas desempenhava um papel de grande relevo, mas ainda traduzia as pressões sociais inerentes às proteções nobiliárquicas e lógicas de parentesco. Daí a necessidade de notarmos que um autor como Severim de Faria não deixava de utilizar seus escritos para difundir uma visão de mundo pontual, no intuito de interferir no debate político de seu tempo. Diante disso, não seria fora de propósito atentarmos para o fato de que, se, por um lado, a invenção de uma tradição pode nortear a construção de um sentido para a escrita do passado, por outro, este procedimento não está desvinculado da especificidade de um contexto em que a lógica de sucessão familiar dinamiza o embate na construção desses sentidos, tal como foi o caso do processo judicial movido por

\footnotetext{
${ }^{18}$ Cf. SARAIVA, António José E LOPES, Óscar, op. cit., p. 542 e 543; Cf. SERRÃO, Joel (dir.). Dicionário de história de Portugal. Castanhoso/Fez. Porto: Livraria Figueirinhas, 1992, s. v. "Faria, pe. Severim de". ${ }^{19}$ Cf. MEGIANI, Ana Paula Torres. Política e letras no tempo dos Filipes: o Império português e as conexões de Manoel Severim de Faria e Luís Mendes de Vasconcelos. In: BICALHO, Maria Fernanda \& FERLINI, Vera Lúcia Amaral. Modos de governar: ideias e práticas políticas no Império português. Séculos XVI-XIX. São Paulo: Alameda, 2005, p. 239-256.
} 
rev. hist. (São Paulo), n. 171, p. 175-212, jul.-dez., 2014 http://dx.doi.org/10.11606/issn.2316-9141.rh.2014.89011
Rubens Leonardo Panegassi

Os artifícios da perfeição: João de Barros por Manuel Severim de Faria

Antônio de Barros de Almeida contra João Batista Lavanha depois que este levara à prensa, em 1615, os manuscritos da Quarta década. ${ }^{20}$

De todo modo, é nítido o quanto o período no qual vigorou a monarquia dual afetou a estrutura sociocultural portuguesa, principalmente por ter despertado problemas no âmbito do pensamento cívico, de modo que o homem de corte se depara com o imperativo de qualificar sua trajetória e reiterar seus elementos de distinção estamental, no intuito de garantir espaço junto ao rei e sua sempre benéfica majestade. Em suma, é sabido que, desde o tempo dos reis católicos, a Monarquia espanhola governava com a assistência dos letrados. ${ }^{21}$ Assim, a reabilitação da memória de um nobre de pluma, tal como João de Barros, assinala o resultado de uma cuidadosa escolha. Com efeito, Bouza Álvarez sugeriu oportunamente que é pequena a presença da nobreza tradicional entre os autores dos séculos XVI e XVII22 e sempre vale lembrar que a "busca da real generosidade aproximava os vassalos do projeto de construção do Estado que, no período, se confundia com a figura do rei". ${ }^{23}$

Assim, fica evidente a tentativa de Manuel Severim de Faria de reabilitar a figura de João de Barros pelo alto serviço prestado à República através de sua arte. Entretanto, a proposta que o biógrafo de João de Barros leva a cabo revela, mais que uma oposição, uma relação pendular entre o tema das armas e das letras. Como sugeriu Ronald Raminelli, um dos tipos de literatura dirigida ao soberano foram as histórias dedicadas a singularizar acontecimentos e heróis, produção que, segundo o autor, "contava como serviço equivalente aos atos de bravura". ${ }^{24}$ Em suma, é a partir desta chave de leitura que podemos compreender o "esquecimento" ao qual os escritores foram submetidos em Portugal, uma vez que, segundo o chantre, o hábito de honrá-los com prêmios públicos

(...) tem cessado há muitos anos, vemos agora isto pelo contrário, sendo muitos os que escrevem histórias de Capitães, e raros os que se ocupam em nos dar notícia dos que as escreveram, particularmente neste reino, onde ainda que não é pequena a falta que temos do conhecimento dos Escritores antigos, e mais para sentir o pouco que

${ }^{20}$ Cf. CURTO, Diogo Ramada. Cultura imperial e projetos coloniais (séc. XV e XVIII). Parte II: Cultura escrita e práticas de identidade (1570 - 1697). Campinas/SP: Editora da Unicamp, 2009.

${ }^{21}$ Cf. BENNASSAR, Bartolomé. La España del siglo de oro. Tradução de Pablo Bordonaba. Barcelona: Crítica, 2010, p. 41

${ }^{22}$ Cf. BOUZA ÁLVAREZ, Fernando, op. cit.

${ }^{23}$ RAMINELLI, Ronald. Viagens ultramarinas: monarcas, vassalos e governo a distância. São Paulo: Alameda, 2008, p. 21.

${ }^{24}$ RAMINELLI, Ronald, op. cit., p. 26. 
rev. hist. (São Paulo), n. 171, p. 175-212, jul.-dez., 2014 http://dx.doi.org/10.11606/issn.2316-9141.rh.2014.89011
Rubens Leonardo Panegassi

Os artifícios da perfeição: João de Barros por Manuel Severim de Faria

comumente se alcança do nosso grande João de Barros, trabalhando ele toda a vida por ilustrar a pátria, e deixar de seus naturais gloriosa memória. ${ }^{25}$

Ora, é válida aqui a assertiva segundo a qual a "confissão das misérias, infortúnios e perseguições sofridos pelos que à escrita se dedicam"26 foi uma das estratégias retóricas mais recorrentes na construção da imagem dos letrados portugueses no período, visto que as biografias também nos remetem a este modelo de representação dos homens de letras. Por sua vez, a "Vida de João de Barros" de Manuel Severim de Faria tem sido apontada como a principal fonte para o estudo da biografia e da bibliografia de João de Barros. ${ }^{27}$ Da importância e notoriedade desta obra, António Baião atenta ainda para o fato de que, nela, Severim de Faria se serviu de "informações orais hoje impossíveis de adquirir". ${ }^{28}$ Importante, portanto, considerar, por um lado, a conotação cívica do texto do chantre. Todavia, por outro lado, não se pode deixar de notar que, para o biógrafo, João de Barros não apenas trabalhou por ilustrar a pátria, mas também para deixar de seus naturais gloriosa memória. Ou seja, Manuel Severim de Faria reconhece o aspecto mnemônico que a obra de João de Barros evoca.

Efetivamente, a reabilitação da figura de João de Barros está articulada ao seu trabalho dedicado à memória de seus naturais. Com efeito, a memória, em sua dimensão coletiva, tem sido posta em jogo, historicamente, na luta das forças sociais pelo poder. Sob esta perspectiva, Jaques Le Goff nos alerta para o fato de que "tornar-se senhores da memória e do esquecimento é uma das grandes preocupações das classes, dos grupos, dos indivíduos que dominaram e dominam as sociedades históricas". ${ }^{29}$ Diante disso, no embate sobre os sentidos do passado, é possível compreender a construção da figura desse autor no âmbito de uma carreira individualizada e a serviço do rei, em oposição às lógicas de sucessão familiar, tão evidentes na disputa judicial

\footnotetext{
${ }^{25}$ FARIA, Manuel Severim de, op. cit., p. IV.

${ }^{26}$ CURTO, Diogo Ramada. O discurso político em Portugal (1600-1650). Lisboa: Projecto Universidade Aberta, 1988, p. 133 e 134.

${ }^{27}$ Cf. SARAIVA, António José \& LOPES, Óscar, op. cit.

${ }^{28}$ BAIÃO, António. Introdução. In: BARROS, João de. Ásia de Joam de Barros. Dos feitos que os portugueses fizeram no descobrimento e conquista dos mares e terras do Oriente. Quarta edição revista e prefaciada por António Baião. Coimbra: Imprensa da Universidade, 1932 (edição fac-similar Lisboa: Imprensa Nacional-Casa da Moeda, 1998), p. V.

${ }^{29}$ LE GOFF, Jaques. Memória. In: História e memória. Tradução de Bernardo Leitão et alii. Campinas, SP: Editora da Unicamp, 2003, p. 422.
} 
rev. hist. (São Paulo), n. 171, p. 175-212, jul.-dez., 2014 http://dx.doi.org/10.11606/issn.2316-9141.rh.2014.89011
Rubens Leonardo Panegassi

Os artifícios da perfeição: João de Barros por Manuel Severim de Faria

movida contra João Batista Lavanha. ${ }^{30}$ Por fim, importa anotar também que a história desempenhou importante papel enquanto fornecedora de exemplos e padrões de comparação no contexto do século XVII português. ${ }^{31}$

Neste sentido, vale atentarmos para o fato de que foi principalmente sob o progresso da memória escrita ao longo da Renascença que este suporte foi colocado a serviço do centralismo monárquico. ${ }^{32}$ No caso de Filipe II, por exemplo, Fernando Bouza Álvares reconhece que a tipografia fez parte das estratégias de propaganda de seu reinado. ${ }^{33}$ Com efeito, notemos, em suma, um caráter que se apresenta duplamente político da "Vida de João de Barros". Por um lado, seu aspecto civil e, por outro, seu esforço de cristalizar elementos para a constituição de uma memória coletiva, fundamentada na continuidade artificial de uma suposta experiência comum.

Pode-se apontar, ainda, um terceiro aspecto da "Vida de João de Barros" que se articula e reforça a dimensão valorativa do caráter civil desse personagem, ainda que sob outro ponto de vista. Trata-se, propriamente, do objeto em questão até o momento, a saber, a narrativa biográfica da vida. Em sua tese sobre Francisco Sá de Miranda, Sérgio Alcides atenta para estas narrativas enquanto aparatos editoriais que reforçavam o vínculo entre a imagem do autor e seu texto. Para ele, o vínculo entre as publicações impressas e o realce da autoria "é uma condição que se generaliza na cultura letrada precisamente ao longo do século XVI, num plano europeu". ${ }^{34}$

Atento ao todo narrativo formado não apenas pela vida, mas também pelo retrato, Sérgio Alcides anota que elementos descritivos tais como a aparência física e os hábitos morais se estabeleceram como regra no gênero biográfico desde a Antiguidade, ${ }^{35}$ quando o ensino das composições orais e escritas era orientado por modelos aprovados de inventividade, arranjo e estilo. Este procedimento, por meio do qual os estudantes deveriam procurar imitar esses modelos, haveria de ser combinado com a emulação, em que o

${ }^{30}$ Cf. CURTO, Diogo Ramada. Cultura imperial..., op. cit.

${ }^{31}$ Cf. CURTO, Diogo Ramada. O discurso político em Portugal..., op. cit.

32 Cf. LE GOFF, Jaques, op. cit.

33 BOUZA ÁLVAREZ, Fernando. Portugal no tempo dos Filipes. Política, cultura, representações (1580-1668). Tradução de Ângela Barreto Xavier e Pedro Cardim. Edições Cosmos, 2000, p. 51 e ss.

${ }^{34}$ AMARAL, Sérgio Alcides Pereira do. Desavenças. Poesia, poder e melancolia nas obras do doutor Francisco de Sá de Miranda. Tese de doutorado, História, FFLCH-USP, 2007, p. 14.

${ }^{35}$ Cf. AMARAL, Sérgio Alcides Pereira do, op. cit., p. 48 e ss. 
exemplo da escrita e da fala aparecia, eventualmente, associado à necessidade de se observar a vida e a moral. ${ }^{36}$

Com efeito, é possível considerar este procedimento de imitação como fenômeno emblemático do início da Época Moderna. Para Federico Chabod, a imitatio pode ser compreendida, precisamente, como uma prática característica do Renascimento europeu, visto que ela incorpora a própria contraposição Renascimento-Medievo sob o aspecto das diferentes maneiras de se relacionar com a cultura clássica. Segundo Chabod, a imitatio é:

(...) a grande palavra que separa o mundo de Cola Di Rienzo do de Hildeberto de Le Mans. Em lugar da combinação entre admiração e deploração por aquilo que já não pode mais renascer, a vontade de atuar em conformidade com tudo quanto se aprende com os antigos, o exercere substitui o legere, e, em lugar da elegia, a exortação à renovação do antigo explendor, a glória de Roma. ${ }^{37}$

Também para Eugenio Garin a imitação é a palavra de ordem do Renascimento. Entretanto, na perspectiva do historiador italiano, é representativa a recorrência da tópica do trabalho da abelha na pena de humanistas como Petrarca ou, mais tarde, Ronsard: ao voar sobre as flores a abelha recolhe o pólen e, a partir dele, faz o mel e a cera. Ou seja, por meio da imitação a tradição é atualizada em diferentes contextos. ${ }^{38}$ De todo modo, o que se verifica, é a permanência da imitação no âmbito das letras portuguesas dos Seiscentos, tal como sugere Maria do Socorro Fernandes de Carvalho:

No final do século XVII, e mesmo na primeira metade do século seguinte, o modelo preceptivo da imitação mantém-se ainda no centro das atenções "dos versados nas letras humanas". Vários elementos textuais indicam essa permanência, entre eles a inclusão de cópias em manuscrito de poemas de autores muito prestigiados, como Francisco de Quevedo, por exemplo, mas também Gôngora e sobretudo Camões, por entre cópias de poemas do Seiscentos tardio e até do século XVIII, momentos em que

\footnotetext{
36 "Convidarei o douto imitador a atentar para o modelo da vida e dos costumes e a partir disto a compor falas vivas". QUINTO HORÁCIO FLACO. Arte poética, linhas 309-318. Tradução de Mauri Furlan. Disponível em: http://www.latim.ufsc.br/986ED7F3-3F3A-4BC2-BBE3-A3514D872AC1. html. Acesso em: 05/08/2011. Cf. também SLOANE, Thomas O. (editor in chief). Encyclopedia of rhetoric. Oxford: Oxford University Press, 2001, s. v. "Imitation".

${ }^{37}$ CHABOD, Federico. Escritos sobre el Renacimiento. Tradução de Rodrigo Ruza. México: FCE, 1990, p. 77. Tradução para o português feita por mim.

${ }^{38}$ Cf. GARIN, Eugenio. La cultura del Rinascimento. Milão, 1988.
} 
rev. hist. (São Paulo), n. 171, p. 175-212, jul.-dez., 2014 http://dx.doi.org/10.11606/issn.2316-9141.rh.2014.89011
Rubens Leonardo Panegassi

Os artifícios da perfeição: João de Barros por Manuel Severim de Faria

os poetas "clássicos do século de ouro" ibéricos haviam, no geral, sido editados e até comentados, em certos casos. ${ }^{39}$

Em suma, nosso interesse é sublinhar que, diante de seu aspecto de síntese física e moral, a vida contribuiu "para o surgimento de uma imagem estável do autor". Imagem que, no seio de uma cultura construída sobre um imperativo pautado na imitação, constituía-se também como exemplo a ser seguido. ${ }^{40}$ Portanto, esta imagem modelar se apresenta alinhada à Antiguidade clássica, já cristalizada enquanto momento ideal da história humana, lugar de realização das mais altas aspirações dos homens e que, sobretudo, haveria de servir de guia - basta recuperarmos, aqui, a leitura feita por Severim de Faria da República de Atenas ao assinalar sua singularidade, "a primeira", e sua exemplaridade, "que ensinou" - para ações elevadas, tanto no campo das letras como no das artes, no da milícia e também no da política.

Esta grade de leitura nos ajuda a compreender o horizonte intelectual que dá sentido à "Vida de João de Barros" em seu contexto de produção. Com isso, é mais uma vez a partir do próprio texto de Manuel Severim de Faria que se pode reiterar o argumento até aqui desenvolvido. Anota o historiador que João de Barros foi:

(...) varão de vida exemplar, e muito piedoso, como se vê bem de suas obras, que podem ser nisso exemplo a outros escritores modernos, os quaes compõem seus livros com tal esquecimento das coisas Divinas, que lidos eles, não se pode determinar se é o autor cristão, se gentio, como já se disse de Joviano Pontano, e de outros. Esta piedade lhe fez procurar por tantas vias o melhoramento dos costumes de seus naturais, compondo tantas obras (.... $)^{41}$

Aqui, Severim de Faria julga que a obra de João de Barros incorpora e deixa transparecer a exemplaridade e piedade que o definem. Desse modo, a singularidade de sua vida e de seu trabalho pode ser generalizada como referência e modelo para outros escritores. E a própria existência de êmulos reitera sua excelência, uma vez que "os maus naturalmente aborrecem os bons por serem contrários a seus costumes". ${ }^{42}$ Sua exemplaridade o associa, ainda, ao desempenho de papéis políticos, ao passo que é considerado

\footnotetext{
39 CARVALHO, Maria do Socorro Fernandes de. Poesia de agudeza em Portugal. São Paulo: Humanitas Editorial; Edusp; Fapesp, 2007, p. 147.

${ }^{40}$ Cf. AMARAL, Sérgio Alcides Pereira do, op. cit.

${ }^{41}$ FARIA, Manuel Severim de, op. cit., p. LVIII.

${ }^{42}$ Idem, ibidem, op. cit.
} 
rev. hist. (São Paulo), n. 171, p. 175-212, jul.-dez., 2014 http://dx.doi.org/10.11606/issn.2316-9141.rh.2014.89011
Rubens Leonardo Panegassi

Os artifícios da perfeição: João de Barros por Manuel Severim de Faria

homem de "grande conselho, prudência, verdade, e crédito", ${ }^{43}$ habilidades fundamentais ao homem de corte. Se, por um lado, a imagem precária das misérias e infortúnios compõe as representações dos letrados, por outro, sua imagem de utilidade também era relevante, de modo que a figura do conselheiro denota a mais ampla interdependência entre o campo intelectual e o político. ${ }^{44}$ Logo, João de Barros alcança "feliz memória, à qual ajudou muito com a artificial". ${ }^{45}$ Está fora de dúvidas, portanto, que esta memória tem algo a ver não apenas com o passado, mas também com a identidade e com sua persistência no futuro. ${ }^{46}$

Em síntese, a composição de um retrato heróico deve ser compreendida à luz da lógica imperativa de uma sociedade estamental, marcada por conflitos de precedência e lugares, em que a utilização sutil de imagens deve ser compartilhada como código referencial, o que implica na confecção da memória dos lugares ocupados pelo herói, bem como de sua própria trajetória no interior desta sociedade. Com efeito, foi por meio da articulação entre as armas e as letras que a aristocracia habilitou-se a ocupar espaços relevantes na corte. Deste processo, Bouza Álvarez nos assegura que ao avançar a "Edad Moderna algunas de las prácticas escritas aristocráticas adoptaron um aire de gesto de distinción de dimensiones casi visuales" ${ }^{47}$

De fato, a vida aristocrática pode ser compreendida como "un escribir que hablaba pintado". ${ }^{48}$ Em suma, a construção da memória do cortesão a partir de uma "pintura que fala" encontra correspondência em uma obra como a Comedia Aulegrafia, de Jorge Ferreira de Vasconcelos. ${ }^{49}$ É neste sentido que devemos considerar a assertiva de Ana Paula Torres Megiani, ao sustentar que ainda nos "séculos XVI e XVII a tradicional oralidade medieval se manteve presente em ambientes cortesãos europeus". ${ }^{50}$ Contudo, esta dimensão política da escrita repercute também a instrumentalização no interior de um de-

\footnotetext{
43 Idem, ibidem, p. LXII.

${ }^{44}$ CURTO, Diogo Ramada, op cit., p. 135 e ss.

${ }^{45}$ FARIA, Manuel Severim de, op. cit., p. LVII.

${ }^{46}$ Cf. ROSSI, Paolo. O passado, a memória, o esquecimento. Seis ensaios da história das ideias. Tradução de Nilson Moulin. São Paulo: Editora Unesp, 2010.

${ }^{47}$ BOUZA ÁlVAREZ, Fernando. Escribir en la corte..., op. cit., p. 84.

${ }^{48}$ BOUZA ÁLVAREZ, Fernando, op. cit., p. 99.

${ }^{49}$ Cf. ALMEIDA, Isabel. Aulegrafia: "rascunho da vida cortesã", "largo discurso da cortesania vulgar". Península. Revista de Estudos Ibéricos, nº 2, 2005, p. 201-218.

${ }^{50}$ MEGIANI, Ana Paula Torres. Contar coisas de todas as partes do mundo: as Relaciones de Sucesos e a circulação de notícias escritas no período filipino. In: ALMEIDA, Suely Creusa Cordeiro de et alii (org.). Cultura e sociabilidades no mundo atlântico. Recife: Ed. Universitária da UFPE, 2012, p. 471.
} 
rev. hist. (São Paulo), n. 171, p. 175-212, jul.-dez., 2014 http://dx.doi.org/10.11606/issn.2316-9141.rh.2014.89011
Rubens Leonardo Panegassi

Os artifícios da perfeição: João de Barros por Manuel Severim de Faria

bate político contextual, de modo que as celebrações do passado podem ser compreendidas como uma das respostas frente à situação da crise política que acompanhou o processo de legitimação de Filipe II diante de Portugal, ${ }^{51}$ ainda que na consciência "de grande parte dos portugueses, a união com a Espanha era uma fatalidade inevitável, da qual era preciso tirar vantagens e evitar inconvenientes possíveis". ${ }^{52}$ Assim, este procedimento pode denotar também um dos instrumentos mais bem acabados daqueles que pretendem exorcizar sua próprias derrotas. ${ }^{53}$

\section{João de Barros cresce}

Ainda que nosso objetivo não seja a elaboração de uma biografia detalhada de João de Barros, importa nos debruçarmos sobre sua trajetória de vida, sobretudo como homem de corte, uma vez que este percurso mostrase associado aos atributos e qualidades de seus escritos. Assim, entramos nitidamente no cerne da imagem do autor, estabilizada não apenas enquanto o responsável pela composição das obras de engenho mas, sobretudo, enquanto aquele que possui credibilidade em função de sua reconhecida autoridade e retidão moral. "Todos os bons autores se hão de ler com estudo"54 escreveria Rafael Bluteau em seu Vocabulário português e latino um século depois de Severim de Faria sem deixar de evocar, porém, a autoridade e o exemplo dos melhores escritores portugueses e latinos. Como exemplo de retidão moral, a conduta deste autor só ganha sentido quando imersa no contexto de sua experiência social concreta que é a vida na corte. A princípio, é possível afirmar unicamente que o cortesão é um dos principais personagens dentre aqueles que emergiram ao longo do início da Época Moderna e que a

\footnotetext{
51 Sobre a posse de Filipe II, sua legitimação diante de Portugal e seus desdobramentos, cf. VILARDAGA, José Carlos. São Paulo na órbita do Império dos Felipes: conexões castelhanas de uma vila da América portuguesa durante a União Ibérica (1580-1640). Tese de doutorado, FFLCH/USP. São Paulo, 2010.

52 MONTEIRO, Rodrigo Bentes. O rei no espelho. A monarquia portuguesa e a colonização da América, 1640-1720. São Paulo: Hucitec, 2002, p. 80.

53 Cf. CURTO, Diogo Ramada. Cultura imperial..., op. cit.

${ }^{54}$ BLUTEAU, Raphael. Vocabulario portuguez, \& latino. Authorizado com exemplos dos melhores escritores portuguezes $\mathcal{E}$ latinos, e offerecido a el rey de Portugal Dom Joam V pelo padre Dom Raphael Bluteau. Lisboa: Na Officina de Pascoal da Sylva, 1712/1728, p. 684. (Os oito volumes que compõem o dicionário foram publicados ao longo de nove anos, a saber: volumes I e II em 1712; III e IV em 1713; volume V em 1716; volumes VI e VII em 1720; e o volume VIII em 1721. Aos oito volumes juntaram-se outros dois de suplementos publicados entre $1727 \mathrm{e}$ 1728, contendo mais de cinco mil vocábulos que não constavam nos volumes anteriores). s. v. "Author". Disponível em: http://www.ieb.usp.br/online/index.asp. Acesso em: 09/08/2011.
} 
rev. hist. (São Paulo), n. 171, p. 175-212, jul.-dez., 2014 http://dx.doi.org/10.11606/issn.2316-9141.rh.2014.89011
Rubens Leonardo Panegassi

Os artifícicos da perfeição: João de Barros por Manuel Severim de Faria

conotação política de sua representação enquanto ideal de vida civil não se afasta dos padrões de honra e dignidade que lhe devem ser característicos.

Com efeito, indício da exemplaridade da vida de João de Barros nos é apresentado em sua própria trajetória enquanto homem de corte. A respeito dessa trajetória até o momento de sua entrada para o paço, a historiografia consultada é imprecisa. Além da "Vida" de Severim de Faria, muito do que se sabe do percurso de João de Barros advém de sua própria obra e do importantíssimo dossiê publicado por António Baião. ${ }^{55}$ Contudo, mesmo em face das dificuldades, João de Barros tem sido visitado com alguma sistematicidade pela historiografia, que nunca deixou de lhe traçar uma síntese biográfica. Dentre alguns estudos de referência, vale mencionar, além do texto fundamental de António Baião, ${ }^{56}$ as contribuições de António Alberto Banha de Andrade, ${ }^{57}$ Charles R. Boxer ${ }^{58}$ e António Borges Coelho. ${ }^{59}$

Assim, embora não haja fontes seguras para atestar a informação, a historiografia aponta o ano de 1496 como data provável de seu nascimento, que teria ocorrido possivelmente na província da Beira, em Viseu, "a mãe que me gerou", tal como afirma o próprio João de Barros referindo-se ao lugar. ${ }^{60}$ Nascido, portanto, dois anos antes da chegada de Vasco da Gama à Índia, é filho de Lopo de Barros, "pessoa nobre e dos principais desta família (...) neto de Álvaro de Barros, senhor do morgado de Moreira".61 Seu pai foi vereador de Viseu e corregedor de Entre-Tejo-e-Odiana. ${ }^{62}$ Ainda a respeito da ascendência de Barros, Severim de Faria enfatiza sua nobreza ao atentar para as memórias das quais sua linhagem "se pode gloriar". ${ }^{63}$ Seu avô, Álvaro de Barros, teria sido fundador do Mosteiro de Requião da Congregação

\footnotetext{
55 Cf. BAIÃO, António (org.). Documentos inéditos sobre João de Barros, sobre o escritor seu homônimo contemporâneo, sobre a família do historiador e sobre os continuadores das suas "Décadas". Boletim da Segunda Classe da Academia das Sciencias de Lisboa, vol. XL, 1917, p. 202-355.

${ }^{56}$ BAIÃO, António, idem, op. cit.

57 ANDRADE, António Alberto Banha de. João de Barros: historiador do pensamento humanista português de Quinhentos. Lisboa: Academia Portuguesa da História, 1980.

${ }^{58}$ BOXER, Charles R. João de Barros, Portuguese humanist and historian of Asia. Nova Delhi: Concept Publishing Company, 1981.

${ }^{59}$ COELHO, António Borges. Tudo é mercadoria. Sobre o percurso e obra de João de Barros. Lisboa: Caminho, 1992; Idem. João de Barros: vida e obra. Lisboa: Grupo de Trabalho do Min. da Educação para as Comemorações dos Descobrimentos Portugueses, 1997.

${ }^{60}$ BARROS, João de. Panegírico da infante dona Maria. Apud COELHO, António Borges. Tudo é mercadoria..., op. cit., p. 17.

${ }^{61}$ FARIA, Manuel Severim de, op. cit., p. V.

${ }^{62}$ Cf. COELHO, António Borges, op. cit.

${ }^{63}$ Cf. FARIA, Manuel Severim de, op. cit., p. VI e COELHO, António Borges, op. cit., p. 20.
} 
rev. hist. (São Paulo), n. 171, p. 175-212, jul.-dez., 2014 http://dx.doi.org/10.11606/issn.2316-9141.rh.2014.89011
Rubens Leonardo Panegassi

Os arrifícicios da perfeição: João de Barros por Manuel Severim de Faria

de São João Evangelista e neto de Martim Martins de Barros, um dos mais antigos fidalgos da linhagem. Além disso, a Casa possuía alguns morgados na região do Minho, "e antigamente tiveram lugares com jurisdição",64 tais como o Perozelo - mercê que foi feita pelo rei dom Pedro a Nuno Fernandes de Barros - e Castro Daire - mercê que foi feita pelo rei dom João I a Gonçalo Nunes de Barros. Por fim, Severim de Faria atenta para os letrados da linhagem e menciona o primo irmão de João de Barros, dom frei Braz de Barros, que foi o primeiro bispo de Leiria. Por sua vez, António Borges Coelho anota que, segundo Manoel Botelho Pereira, o pai de João de Barros foi criado de Afonso V, de dom João II e de dom Manuel, tendo participado da tomada de Arzila e capitaneado "um esquadrão no cerco do Sabugal durante as guerras luso-castelhanas do Africano". ${ }^{65}$ Contudo, embora se saiba relativamente bastante a respeito de seu pai, não há qualquer menção a respeito da figura materna, claro indício de bastardia.

Sobre a entrada de João de Barros para o paço, Severim de Faria nos revela ter ido a "serviço do Rei Dom Manuel de tão poucos anos, que ele mesmo confessa que à idade do jogo de pião". ${ }^{66}$ Ou seja, entrou para a corte quando era ainda uma criança, e possivelmente mediado por um nobre da mais alta estirpe, dom João de Meneses - prior do Crato e mordomo-mor do rei dom Manuel -, amigo de Lopo de Barros. ${ }^{67}$ Esse fato nos revela algo a respeito dessa instituição social e sua lógica enquanto uma sociedade de raízes medievais, cuja persistência na primeira modernidade é o mais notável indício de sua importância como um circuito social em que se teciam redes de interdependência. ${ }^{68}$ Realmente, como assinalou Diogo Ramada Curto, "as possibilidades de carreira, no interior da corte, não são independentes da configuração das facções que aí existem". ${ }^{69}$ Em vista disso, a trajetória da vida de João de Barros descrita por Severim de Faria nos revela ter sido ele muito bem amparado no ambiente cortesão.

Tal como sugeriu oportunamente Peter Burke, embora não seja fácil dizer exatamente o que era um cortesão, ele pode ser compreendido, junta-

${ }^{64}$ Cf. FARIA, Manuel Severim de, op. cit., p. VII.

${ }^{65}$ Cf. COELHO, António Borges, op. cit., p. 20.

${ }^{66}$ FARIA, Manuel Severim de, op. cit., p. VII.

${ }^{67}$ Cf. COELHO, António Borges, op. cit., p. 21.

${ }^{68}$ Cf. BURKE, Peter. O cortesão. In: GARIN, Eugenio. O homem renascentista. Tradução de Maria Jorge Vilar de Figueiredo. Lisboa: Editorial Presença, 1991, p. 101-119.

${ }^{69}$ CURTO, Diogo Ramada. A cultura política. In: MATTOSO, José (dir.). História de Portugal, $3^{\circ}$ volume: No alvorecer da modernidade. Lisboa: Editorial Estampa, 1997, p. 112. 
rev. hist. (São Paulo), n. 171, p. 175-212, jul.-dez., 2014 http://dx.doi.org/10.11606/issn.2316-9141.rh.2014.89011
Rubens Leonardo Panegassi

Os artifícios da perfeição: João de Barros por Manuel Severim de Faria

mente com o humanista - figura com a qual muitas vezes se confunde - e o príncipe, como um dos personagens de maior visibilidade da Renascença, cuja vida orbitava em torno da corte. Por sua vez, a corte, além do palácio em si, composto de pátios, salões e aposentos, era um tipo especial de instituição à medida que abrigava o rei..$^{70}$ "O lugar onde reside o Rei, assistido dos oficiais e ministros da Casa real", ${ }^{\prime 1}$ como definiria Raphael Bluteau. Grosso modo, portanto, e tendo em vista principalmente a ideia inerente à noção de Casa real, é possível compreender a corte como a "família" de um soberano frente a quem servirá, sempre, de paradigma. O próprio João de Barros escreveria no Panegírico do rei dom João III não haver "coisa mais prejudicial ao vassalo que o mau costume ou defeito do senhor".72 Com efeito, Emmanuel Le Roy Ladurie aponta para o fato de que a monarquia liga-se estreitamente ao funcionamento da corte, "centrada em torno do soberano",75 de modo que "a corte erige-se em lugar geométrico das hierarquias"74 e, efetivamente, sustenta o sistema monárquico.

Ainda no que tange aos cortesãos, é importante considerá-los sob o signo da heterogeneidade, visto que havia uma classificação hierárquica das várias figuras de cortesãos. Sobre essa hierarquia, é Le Roy Ladurie quem nos dá notícias:

O espírito hierárquico fixa-se em alguns aspectos: subdivisão cada vez mais extensa das posições, ao longo de um eixo vertical, que desce da família real aos simples fidalgos, passando pelos duques e pares. Referência às distinções entre o sagrado e o profano; também entre o puro e o impuro, o bastardo e o legítimo. ${ }^{75}$

Por sua vez, como sublinhou Peter Burke, o topo dessa hierarquia era ocupado por aristocratas aos quais eram delegados cargos de grande prestígio social, tais como o de camareiro, de senescal ou de escudeiro. Estes cargos possuíam caráter fundamentalmente doméstico, em que o camareiro

\footnotetext{
${ }^{70}$ Cf. BURKE, Peter, op. cit.

${ }^{71}$ BLUTEAU, Raphael, op. cit. s. v. "Corte". Disponível em: http://www.ieb.usp.br/online/index. asp. Acesso em: 19/08/2011.

${ }^{72}$ BARROS, João de. Panegírico do rei dom João III. In: Panegíricos (Panegírico de dom João III e da infanta dona Maria). Texto restituído, prefaciado e notas pelo prof. M. Rodrigues Lapa. Lisboa: Livraria Sá da Costa, 1943. p. 7.

73 LADURIE, Emmanuel Le Roy. O Estado monárquico, França, 1460-1610. Tradução de Maria Lúcia Machado. São Paulo: Companhia das Letras, 1994, p. 14.

${ }^{74}$ LADURIE, Emmanuel Le Roy, op. cit., p. 15.

${ }^{75}$ LADURIE, Emmanuel Le Roy, op. cit., p. 15.
} 
rev. hist. (São Paulo), n. 171, p. 175-212, jul.-dez., 2014 http://dx.doi.org/10.11606/issn.2316-9141.rh.2014.89011
Rubens Leonardo Panegassi

Os artifícios da perfeição: João de Barros por Manuel Severim de Faria

deveria tratar dos aposentos e das roupas do príncipe, o grão-senescal cuidaria de sua comida e o escudeiro se dedicaria aos cavalos. Todavia, essas funções eram exercidas apenas em ocasiões especiais e ritualizadas. ${ }^{76}$ As funções domésticas eram um privilégio que obedecia uma hierarquia precisa. Segundo Norbert Elias, pai da matéria:

(...) depois que um determinado sistema de privilégios estava estabilizado em seu equilíbrio, nenhum dos privilégios podia abandoná-lo sem tocar nesses privilégios, que constituiam a base de toda a sua existência pessoal e social. ${ }^{77}$

Destarte, essa hierarquia deveria marcar os graus de aproximação entre o cortesão e o monarca sem deixar transparecer preferências e impedir que se criassem desigualdades marcantes, fato que bastaria para extravasar o legalmente fixado e aceite. De acordo com Joaquim Romero Magalhães, a "distância cortesã libertaria o monarca de influências e favoritismos, pondo-o acima e fora das facções" ${ }^{78}$ Todavia, embora essa distância, associada à difusão de um comportamento ritualizado no serviço aos príncipes seculares tenha afirmado sua autoridade diante de seus cortesãos subordinados, não se pode perder de vista que "um papel importante na corte era desempenhado pelos chamados 'favoritos'", pois "faziam companhia ao soberano no seu tempo livre, tal como os conselheiros passavam com ele as horas de trabalho".79 Vale matizar, entretanto, que embora a história das monarquias modernas tenha sido marcada pela figura de criados ou ministros em que o soberano depositasse maior confiança, o auge dos favoritos nos remete ao início do século XVII. ${ }^{80}$

Em síntese, a honra de cada cortesão passava pela definição de seu lugar na corte, lugar onde o rei deveria aspirar à distância majestática, no intuito de sinalizar sua autoridade soberana. Uma vez alcançada esta posição de supremacia, o soberano teria, abaixo de si, seus súditos, "obrigados à obediência". Assim, enquanto centro de poder e também enquanto referencial paradigmático, o grau de proximidade com o rei se constituía como um

\footnotetext{
${ }^{76}$ Cf. BURKE, Peter, op. cit.

77 ELIAS, Norbert, op. cit., p. 105.

${ }^{78}$ MAGALHÃES, Joaquim Romero. As estruturas políticas de unificação: o rei. In: MATTOSO, José (dir.). História de Portugal, $3^{\circ}$ volume: No alvorecer da modernidade. Lisboa: Editorial Estampa, 1997, p. 66.

${ }^{79}$ BURKE, Peter, op. cit., p. 105.

${ }^{80}$ Cf. THOMPSON, I. A. A. El contexto institucional de la aparición del ministro-favorito. In: ELLIOTT, John $\mathcal{E}$ BROCKLISS, Laurence (dir.). El mundo de los validos. Tradução de Jesús Alborés e Eva Rodríguez Halfter. Madri: Taurus, 2000, p. 25-41.
} 
rev. hist. (São Paulo), n. 171, p. 175-212, jul.-dez., 2014 http://dx.doi.org/10.11606/issn.2316-9141.rh.2014.89011
Rubens Leonardo Panegassi

Os artifícios da perfeição: João de Barros por Manuel Severim de Faria

ideal que orientaria as práticas dos cortesãos. ${ }^{81}$ Efetivamente, ao passo que a proximidade com a figura do rei se impunha como necessária no cálculo da carreira do cortesão, é visível que a fixação da imagem do cortesão ideal reifica este procedimento como elemento de diferenciação da singularidade do cortesão e de sua carreira.

No caso de João de Barros, a "Vida" atesta sua proximidade com dom João III uma vez que, de acordo com o escrito de Manuel Severim de Faria, o rei dom Manuel o entregaria "ao príncipe Dom João por seu moço de guarda-roupa, quando lhe assentou casa". ${ }^{82}$ Vale notar que esta relação doravante inextrincável assinalará o caráter da obra de João de Barros, uma vez que não é possível "analisar o discurso histórico independentemente da instituição em função do qual ele se organiza". ${ }^{35}$ Entretanto, sem perder de vista nosso foco na construção da imagem desse historiador enquanto cortesão exemplar, vale sublinhar que o privilégio a ele concedido não apenas lhe confere a dignidade de uma estreita relação com o príncipe dom João, mas, sobretudo, vem coroar sua diligência enquanto cortesão. Com efeito, segundo Manuel Severim de Faria, quando João de Barros entrou para o paço:

Costumavam naquele tempo os reis de Portugal mandar doutrinar os moços fidalgos e os da câmara, de que se serviam, em toda boa disciplina. E tinham para isso mestres no Paço que lhes ensinavam as línguas, ciências matemáticas, letras humanas, dançar, jogar as armas, e outros virtuosos exercícios. E os mestres tinham certo dia no mês em que o Rei sabia deles quem bem exercitava estas artes ou se havia remisso e negligente nelas. E era tão grande a benignidade daqueles príncipes, que se lembravam de louvar a uns e repreender aos outros, no que muitos se ascendiam nos desejos de aprender. Estes foram os claros estudos, em que João de Barros cultivou seu engenho. ${ }^{84}$

Foi, portanto, sob a observância de dom Manuel que João de Barros "se avantajou tanto a seus condiscípulos" e foi nomeado moço de guarda-roupa. Sua nomeação obedecia, portanto, a uma rígida regulamentação que reiterava o ordenamento da corte e atendia àquilo que seria o ideal na formação do cortesão. Realmente, sua vivência no paço se adequou à exigência de uma formação intelectual abrangente, cujo acesso somente lhe fora garantido pela oportunidade de viver no âmbito da corte. Com efeito, segundo o historiador

\footnotetext{
${ }^{81}$ Cf. CURTO, Diogo Ramada, op. cit.

${ }^{82}$ FARIA, Manuel Severim de, op. cit., p. VIII.

${ }^{83}$ CERTEAU, Michel de. A escrita da história. Tradução de Maria de Lourdes Menezes; revisão técnica de Arno Vogel. Rio de Janeiro: Forense Universitária, 2000, p. 71.

${ }^{84}$ FARIA, Manuel Severim de, op. cit., p. VII-VIII.
} 
rev. hist. (São Paulo), n. 171, p. 175-212, jul.-dez., 2014 http://dx.doi.org/10.11606/issn.2316-9141.rh.2014.89011
Rubens Leonardo Panegassi

Os artifícios da perfeição: João de Barros por Manuel Severim de Faria

Perry Anderson, esta formação intelectual foi uma exigência do novo papel que a aristocracia assumiu a partir do fim da Idade Média. Para o inglês, os aristocratas tiveram "que aprender as novas ocupações de um oficial disciplinado, um funcionário letrado, um polido cortesão e um proprietário de terras mais ou menos prudente".$^{85}$

Assim, para atentarmos de modo mais detalhado àquilo que seria a possível formação de um cortesão português na virada do século XV para o XVI, vale nos determos no que escreveu Baldassare Castiglione em seu livro $O$ cortesão, uma vez que pode nos dar a exata medida do modelo ideal que viria a servir de referência para a formação intelectual enciclopédica desse personagem ainda no decorrer do século XVI. Dedicado a dom Miguel da Sylva, bispo de Viseu, o livro de Baldassare Castiglione veio à luz na primeira metade do século XVI, mais precisamente em abril de 1528 e delineia a imagem daquele que seria o perfeito homem de corte: possuir origem irredutivelmente nobre e conhecer com propriedade a poesia, a história, a retórica, a música, as artes e a filosofia moral, sendo que seria este último campo de conhecimento que lhe permitiria dominar os rudimentos necessários às exigências de prudência e discrição, virtudes necessárias à vida palaciana. ${ }^{86}$

Sobre o cortesão Castiglione pretendia que:

(...) nas letras ele [o cortesão] seja mais que medianamente erudito, pelo menos nestes estudos que chamamos de humanidades, e não somente da língua latina, mas também da grega tenha conhecimentos para as muitas e várias coisas que nelas estão divinamente escritas. Seja versado nos poetas e não menos nos oradores e historiadores, e exercitado também em escrever versos e prosa, especialmente nesta nossa língua vulgar; pois, além do contentamento que ele próprio terá, com isso nunca lhe faltarão prazerosos entretenimentos com as mulheres, que, em geral, apreciam tais coisas (... $)^{87}$

Efetivamente, a "Vida de João de Barros" nos apresenta uma figura bem acabada do homem de corte, sobretudo em vista de alguns já mencionados aspectos de sua trajetória, tais como sua origem irredutivelmente nobre, a residência na corte desde a mocidade, sua proximidade com o rei e sua sólida formação erudita, tendo em vista que "aprendeu a língua latina e grega, e

\footnotetext{
${ }^{85}$ ANDERSON, Perry. Linhagens do Estado absolutista. Tradução de João Roberto Martins Filho. São Paulo: Brasiliense, 2004, p. 47.

${ }^{86}$ Cf. PÉCORA, Alcir. Prefácio à edição brasileira. A cena da perfeição. In: CASTIGLIONE, Baldassare, conte. $O$ cortesão. Tradução de Carlos Nilson Moulin Louzada. São Paulo: Martins Fontes, 1997, p. VII-XV.

${ }^{87}$ CASTIGLIONE, Baldassare, conte, op. cit., p. 67.
} 
rev. hist. (São Paulo), n. 171, p. 175-212, jul.-dez., 2014 http://dx.doi.org/10.11606/issn.2316-9141.rh.2014.89011
Rubens Leonardo Panegassi

Os artifícios da perfeição: João de Barros por Manuel Severim de Faria

as ciências matemáticas e letras humanas com grande perfeição. Entre os poetas se deu mais à lição de Virgílio e Lucano, e nos historiadores à de Salustio e Lívio". ${ }^{88}$ A importância da formação do cortesão deve ser compreendida, portanto, no âmbito de um espaço em que o "trato dos príncipes e a comunicação das pessoas que andão junto a eles"89 é o primeiro e principal exercício. Do ato de comunicação na corte e sua relevância é o próprio João de Barros quem nos dá seu testemunho. Segundo ele, a "conversação de homens especiais e de grandes qualidades" constitui o essencial do "saber cortesão".90

Entretanto, além das condições e das etapas que devem ser galgadas pelo cortesão ideal, tais como a de possuir uma origem nobre, residir na corte desde a mocidade, ter proximidade com o rei e ter uma sólida formação, Diogo Ramada Curto assinala que o serviço nos cargos da guerra é um passo importante na carreira ideal do homem de corte. ${ }^{91}$ Em vista disso, faz sentido que, na composição da carreira exemplar de João de Barros, Manuel Severim de Faria tenha sugerido que dom João III nomeara o historiador para servir na capitania da Mina.. ${ }^{2}$ Asserção que, muitas vezes, ecoa na historiografia dedicada ao autor das Décadas, como é o caso do artigo assinado por Rafael Moreira e William M. Thomas, publicado na revista Oceanos, em que os autores afirmam que João de Barros governara São Jorge de Mina entre 1522 e 1525, ou no livro $O$ redemunho do horror, de Luiz Costa Lima, no qual o autor nos assegura que João de Barros foi agraciado com a capitania da Mina. ${ }^{93}$

De fato, tendo em vista a dignidade que Manuel Severim de Faria empresta a João de Barros na construção de seu retrato heróico, seria natural que ele tivesse ocupado tal cargo, uma vez que a dignidade do ofício denota a digni-

\footnotetext{
${ }^{88}$ FARIA, Manuel Severim de, op. cit., p. VIII.

${ }^{99}$ Cf. LOBO, Francisco Rodrigues. Corte na aldeia e noites de inverno. Affonso Lopes Vieira (ed.). Lisboa: Sá da Costa, 1945; Adriano de Carvalho (ed.). Lisboa: Presença, 1992, p. 256. Apud CURTO, Diogo Ramada, op. cit., p. 111.

${ }^{90}$ Cf. BARROS, João de. Ropicapnefma, volume II. Reprodução fac-similada da edição de 1532 Leitura modernizada, notas e estudo de I. S. Révah. Lisboa: Instituto Nacional de Investigação Científica, 1983, p. 56. Cf. também CURTO, Diogo Ramada, op. cit., p. 111. Agradeço à colega Juliana Fujimoto pela assistência nesta nota e na anterior.

${ }^{91}$ Cf. CURTO, Diogo Ramada, op. cit., p. 112.

${ }^{92}$ Cf. FARIA, Manuel Severim de, op. cit., p. X.

${ }^{93}$ Cf. MOREIRA, Rafael \& THOMAS, William M. Desventuras de João de Barros primeiro colonizador do Maranhão - O achado da nau de Aires da Cunha naufragada em 1536. Oceanos. João de Barros e o cosmopolitismo do Renascimento, $n^{\circ}$ 27. Lisboa: Comissão Nacional para a Comemoração dos Descobrimentos Portugueses, julho/setembro, 1996, p. 102 e LIMA, Luiz Costa. O redemunho do horror: as margens do Ocidente. São Paulo: Editora Planeta do Brasil, 2003, p. 41, nota 5.
} 
dade de cada um. ${ }^{4}$ Em suma, não se pode perder de vista que, nesse contexto, a representação ideal de vida civil não deve prescindir dos padrões de honra e dignidade que devem caracterizar o personagem em questão. Como observamos anteriormente, é relevante a confecção da memória dos lugares ocupados pelo herói. Destarte, nesse ponto específico da trajetória do historiador quinhentista - em que ele teria capitaneado a cidade de São Jorge da Mina -, é possível revisar com segurança a afirmação de Severim de Faria e sugerir um redimensionamento da efetiva dignidade do historiador quinhentista.

\section{Da efetiva dignidade de João de Barros}

A compreensão do significado efetivo que o cargo de capitão da cidade de São Jorge da Mina ganha no contexto social da vida da corte portuguesa pode ser alcançado quando observamos a história desta cidade. Contudo, antes de recuperarmos sua trajetória histórica, vale atentarmos para o fato de que tal cargo era, efetivamente, uma função da mais extrema importância e, por isso, é verossímil a afirmação de que João de Barros a tenha capitaneado: tanto em função de sua importância no asseguramento da presença portuguesa no golfo de Guiné como também pelo fato de que São Jorge da Mina se constituiu como resultado das históricas disputas entre os reinos de Portugal e de Castela.

Por sua vez, a solução de tais disputas só foi alcançada com o Tratado de Alcáçovas de 4 de setembro de 1479, em que se concertava que Portugal ficaria obrigado a renunciar a quaisquer direitos à Coroa castelhana, bem como abandonar suas reivindicações sobre as Canárias ou projetos de caráter militar contra Granada. Por outro lado, este mesmo tratado determinaria que o reis dom Fernando de Aragão e dona Isabel de Castela reconhecessem o monopólio português no comércio da Guiné. ${ }^{95}$

O Tratado de Alcáçovas foi, portanto, um instrumento político fundamental, ao menos em tese, para a garantia da presença lusa no golfo de Guiné. Por isso, é relevante o valor simbólico de tal conquista, principalmente se não perdermos de vista que, para o o português quinhentista, ela poderia muito bem significar a primeira etapa de um processo expansivo de impulso cruzadístico cujo ápice seria o retorno de Vasco da Gama de sua viagem à

${ }^{94}$ Cf. HESPANHA, António Manuel. Imbecillitas. As bem-aventuranças da inferioridade nas sociedades de Antigo Regime. São Paulo: Annablume, 2010.

${ }^{95}$ Cf. ALBUQUERQUE, Luís de (dir.) E DOMINGUES, Francisco Contente (coord.). Dicionário de história dos descobrimentos portugueses, vol. II. Lisboa: Caminho, 1994. s. v. "Mina, Feitoria e fortaleza da". 
rev. hist. (São Paulo), n. 171, p. 175-212, jul.-dez., 2014 http://dx.doi.org/10.11606/issn.2316-9141.rh.2014.89011
Rubens Leonardo Panegassi

Os artifícios da perfeição: João de Barros por Manuel Severim de Faria

Índia no ano de 1499. Charles R. Boxer nos dá uma medida aproximada da importância do feito para Portugal:

A tomada de Ceuta pelos portugueses, em agosto de 1415, e, ainda mais importante, o fato de a terem conservado, foram provavelmente inspirados pelo ardor de cruzados que visavam desferir um golpe nos infiéis, e pelo desejo dos príncipes de Portugal, semi-ingleses, de serem teatralmente armados cavaleiros no campo de batalha. ${ }^{96}$

Entretanto, essa presença somente seria assegurada em termos mais concretos com a construção de uma fortaleza na região, que foi levada a cabo pelo entusiasmo imperialista de dom João II, o "Príncipe perfeito". Desse modo, interessava-se pessoalmente pelo comércio e, com isso, procurava garantir os interesses portugueses no golfo da Guiné contra possíveis intrusos - tanto de espanhóis quanto de outros europeus -, bem como intimidar as tribos por intermédio das quais o ouro era adquirido e, por fim, resguardar os portugueses de possíveis ataques de indígenas africanos.97

Localizada numa região que compreendia o território situado entre o cabo das Palmas e o rio Volta, a ação portuguesa na Mina foi orientada pela ocupação segura de pontos estratégicos no litoral africano sem, contudo, penetrar para o interior do continente. Seu principal papel comercial era o de atrair as tradicionais rotas africanas de comércio de escravos e ouro. Desempenhando, portanto, um papel passivo neste comércio - vale lembrarmos que o tráfico de escravos, por exemplo, envolvia a participação ativa de líderes africanos -, a diplomacia local do governador de São Jorge se configurava como um instrumento da maior importância para garantir segurança à presença portuguesa. Sendo assim, a feitoria-fortaleza de São Jorge da Mina foi a sede de todos os estabelecimentos portugueses na costa do golfo de Guiné entre os anos de 1482 e $1637 . .^{98}$ Todavia, é preciso anotar que a Coroa portuguesa jamais exerceu jurisdição efetiva na África ocidental para além dos limites de suas feitorias.99

Por sua vez, António Borges Coelho nos apresenta uma brevíssima descrição do modo como a fortaleza de São Jorge da Mina estava ordenada.

\footnotetext{
${ }^{96}$ BOXER, Charles R. O império marítimo português, 1415 - 1825. Tradução de Anna Olga de Barros Barreto. São Paulo: Companhia das Letras, 2002, p. 34.

${ }^{97}$ Cf. AlbUQUeRQUE, Luís de (dir.) \& DOMINGUES, Francisco Contente (coord.), op. cit., s. v. "Mina, Feitoria e fortaleza da". Cf. também BOXER, Charles R., op. cit., p. 47 e 48.

${ }^{98} \mathrm{Cf}$. Idem, ibidem.

${ }^{99}$ Cf. BOXER, Charles R., op. cit., p. 47.
} 
rev. hist. (São Paulo), n. 171, p. 175-212, jul.-dez., 2014 http://dx.doi.org/10.11606/issn.2316-9141.rh.2014.89011
Rubens Leonardo Panegassi

Os artifícios da perfeição: João de Barros por Manuel Severim de Faria

Segundo o historiador, os funcionários principais da fortaleza eram, em ordem descendente, "o capitão, o alcaide-mor e o feitor, os escrivães, o feitor da roupa velha (roupa das tripulações e do rei vendida legalmente no mercado), o meirinho, o vigário e os clérigos, o almoxarife dos mantimentos, o vedor do forno" e, por fim, a imprescindível função de vendedor de vinho. ${ }^{100}$

Dentre os capitães - ou capitães governadores - dessa feitoria-fortaleza, Diogo de Azambuja foi o primeiro a assumir o cargo e, entre seus sucessores, Diogo Lopes de Sequeira e Duarte Pacheco Pereira. Este último nos deixa algumas informações a respeito da história e da importância do lugar em seu fundamental Esmeraldo de situ orbis, redigido entre os anos de 1505 e 1507:

(...) o excelente Rei Dom Afonso o quinto mandou descobrir da serra Leoa, donde o Infante acabou, em diante toda a costa da Malagueta e a Mina, e do rio dos Escravos até o cabo de Caterina, que será por costa, além da dita serra Leoa, seiscentas e cinquenta léguas.

Descobertas todas estas regiões e províncias, e finado o Rei Dom Afonso, veio esta mesma conversão ao sereníssimo Príncipe o Rei Dom João o segundo, seu filho, que é tão digno de imortal lembrança; o qual, com muito desejo de acrescentar no comércio e riqueza deste reinos, mandou descobrir as ilhas de São Tomé e Santo Antonio e as povoou com fundamento da navegação da Índia; se lhe Nosso Senhor dera vida, devemos crer que ele a descobrira; e também mandou fazer do primeiro fundamento à cidade de São Jorge da Mina, da qual tanta utilidade Vossa Alteza e vossos reinos recebem; e por não alargar mais matéria, deixo de dizer as particularidades de muitas coisas que este glorioso Príncipe mandou descobrir por mim e por outros seus capitães em muitos lugares e rios da costa da Guiné, dos quais, em tempo do Infante Dom Henrique e o Rei Dom Afonso, a costa do mar somente era sabida sem se saber o que dentro neles era. ${ }^{101}$

Com efeito, na pena de Duarte Pacheco Pereira, o reino português recebe muita utilidade de São Jorge da Mina, e a descoberta de lugares e rios são atividades que figuram entre os feitos do capitão da fortaleza. Neste sentido, não se pode perder de vista o fato de que o serviço nos cargos da guerra era um importante passo na trajetória do cortesão e, por isso, Manuel Severim de Faria nos faz crer que dom João III nomeara João de Barros à capitania da Mina, posição que pode ser considerada como um cargo militar, principal-

\footnotetext{
${ }^{100}$ COELHO, António Borges. Tudo é mercadoria..., op. cit., p. 28.

${ }^{101}$ PEREIRA, Duarte Pacheco. Esmeraldo de situ orbis. In: CARVALHO, Joaquim Barradas de. Esmeraldo de situ orbis de Duarte Pacheco Pereira. Edição crítica e comentada. Lisboa: Fundação Calouste Gulbenkian/Serviço de Educação, 1991, p. 531 e 532. O grifo é meu.
} 
rev. hist. (São Paulo), n. 171, p. 175-212, jul.-dez., 2014 http://dx.doi.org/10.11606/issn.2316-9141.rh.2014.89011
Rubens Leonardo Panegassi

Os artifícios da perfeição: João de Barros por Manuel Severim de Faria

mente quando atentamos para o fato de que "o governo militar das praças transita dos alcaides-mores para os capitães das fortalezas". ${ }^{102}$

Todavia, se nos determos no estudo introdutório feito por António Baião para a Ásia de João de Barros, é possível recolocar a efetiva trajetória do historiador quinhentista. Porém, diferentemente de António Baião, que se propôs a ratificar algumas informações transmitidas por Manuel Severim de Faria - embora nos valendo do legado de sua excelente e erudita pesquisa -, nesse momento, nossa investigação pretende se deter naquilo que possivelmente tenha levado Manuel Severim de Faria a escrever o que escreveu. ${ }^{103}$ Contudo, julgamos insuficiente considerar, aqui, a hipótese de que Severim de Faria escreveu o que escreveu porque não teve acesso à informação correta. É evidente que isso pode ser verdade. Entretanto, esta não é a questão. Nossa questão, aqui, é problematizar as possíveis convenções intelectuais que regeram o tratamento dessa temática em seu texto.

António Baião anota que, em suas Décadas, João de Barros não faz qualquer menção à sua situação oficial no momento em que registra sua viagem para o castelo da Mina. ${ }^{104} \mathrm{O}$ grande historiador da literatura portuguesa, António José Saraiva, corrobora a assertiva de Baião ao afirmar que João de Barros fez "apenas uma viagem até São Jorge da Mina". ${ }^{105}$ Na mesma linha, Charles R. Boxer afirma que não há nenhuma fonte coeva que comprove que o historiador quinhentista tenha ocupado este cargo. Além disso, Boxer sugere, com maestria, que seria pouco provável que um cargo de tamanha importância fosse dado a alguém tão jovem e inexperiente e, ainda, arrisca a hipótese de que João de Barros foi enviado à fortaleza de São Jorge da Mina para uma visita de inspeção, ou, possivelmente, para realizar alguma missão especial breve. ${ }^{106}$

Por sua vez, se retomamos o estudo de António Baião, não é possível deixar de notar sua menção de que, no primeiro ano do reinado de dom João III, ou seja, o de 1522, em registro de quatro de julho, consta a nomeação de dom Afonso de Albuquerque - ao que tudo indica, homônimo do

\footnotetext{
${ }^{102}$ SERRÃO Joel (dir.). Dicionário..., op. cit., s. v. "Capitão".

${ }^{103}$ Sobre a elaboração dessa problemática remeto ao seguinte artigo: SKINNER, Quentin. Motives, intentions and the interpretation of texts. New Literary History, vol. 3, $\mathrm{n}^{\mathrm{o}}$ 2, On Interpretation: I, Winter, 1972, p. 393-408.

${ }^{104}$ Cf. BARROS, João de. Da Ásia de João de Barros. Dos feitos que os portugueses fizeram no descobrimento e conquista dos mares e terras do Oriente, década terceira, parte primeira, livro III, capítulo I. Lisboa: Na Regia Oficina Tipográfica, 1777, p. 235/236.

${ }^{105}$ SARAIVA, António José. Uma concepção planetária de história em João de Barros. In: Para a história da cultura em Portugal, volume II. Lisboa: Publicações Europa-América, 1972, p. 353/354.

${ }^{106}$ BOXER, Charles R. João de Barros, Portuguese humanist and historian of Asia..., op. cit., p. 26.
} 
rev. hist. (São Paulo), n. 171, p. 175-212, jul.-dez., 2014 http://dx.doi.org/10.11606/issn.2316-9141.rh.2014.89011
Rubens Leonardo Panegassi

Os artifícios da perfeição: João de Barros por Manuel Severim de Faria

famoso conquistador e colonizador - como capitão da cidade portuguesa de São Jorge da Mina em substituição a Duarte Pacheco, tal como se pode conferir no excerto que segue:

Dom João etc. A quantos esta nossa carta virem fazemos saber que, confiando-nos da bondade e descrição de Dom Afonso de Albuquerque, fidalgo de nossa Casa e por que somos certo que em todo o que o encarregarmos, nos há de servir bem e fielmente com aquele cuidado e Recado que se dele espera, havendo, além de tudo, Respeito a seus serviços e merecimentos, temos por bem e o damos por capitão de nossa cidade de São Jorge da Mina pelo tempo contido em nosso Regimento, assim e por a maneira que o até aqui foi Duarte Pcheco que a dita capitania teve com todo o mantimento (...) percalços e poderes, honras, liberdades a ele ordenados e contidos no dito Regimento e provisões nossas que para isso leva; notifica-mo-lo assim ao dito Duarte Pacheco e lhe mandamos que, tanto que esta vir, entregue a fortaleza da dita cidade ao dito Dom Afonso com todo o que nele estiver sem falecer coisa alguma e assim mandamos ao feitor e oficiais e moradores e quaisquer pessoas outras que na dita cidade estiverem que hajam ao dito Dom Afonso por capitão dela e obedeçam em todo o que ele mandar, assim como se acostuma fazer aos nossos capitães por quanto nos fazemos mercê da dita capitania ao dito Dom Afonso, como dito é por esta nossa carta que lhe mandamos dar por nós assinada e selada do nosso selo. ${ }^{107}$

Frente a esta evidência, António Baião nos remete à quitação dada a João de Barros como tesoureiro da Casa da Índia, na qual é possível ler o seguinte:

Dom Sebastião etc. faço saber a quantos esta minha carta de quitação virem, que el Rei meu senhor e avô que santa glória haja, mandou tomar conta ao feitor João de Barros, que serviu de tesoureiro do dinheiro da Casa da Índia e assim de tesoureiro da Casa da Mina e de tesoureiro mor da Casa de Ceuta de tempo de três anos e oito meses, que começaram ao primeiro dia do mês de Maio de 1525 e acabaram em fim de dezembro de 1528 e, pela arrecadação de sua conta, se mostra receber de dinheiro oitocentos e noventa e três contos, novecentos e setenta e cinco mil, duzentos e trinta. ${ }^{108}$

Com isso, António Baião observa o fato de que João de Barros teria exercido os cargos de tesoureiro do dinheiro da Casa da Índia, o de tesoureiro da Casa da Mina e o de tesoureiro-mor da Casa de Ceuta ao longo de

\footnotetext{
${ }^{107}$ Nomeação de dom Afonso de Albuquerque para a capitania da São Jorge da Mina. Chancelaria de dom João III, liv. 5 I, fl. 184 v. Apud. BAIÃO, António. Introdução. In: op. cit., p. X. O grifo é meu. ${ }^{108}$ Quitação dada a João de Barros como tesoureiro da Casa da Índia. In: BAIẪO, António (org.). Documentos inéditos sobre João de Barros, sobre o escritor seu homônimo contemporâneo, sobre a família do historiador e sobre os continuadores das suas "Décadas". Boletim da Segunda Classe da Academia das Sciencias de Lisboa, vol. XL, 1917, p. 202. O grifo é meu.
} 
rev. hist. (São Paulo), n. 171, p. 175-212, jul.-dez., 2014 http://dx.doi.org/10.11606/issn.2316-9141.rh.2014.89011
Rubens Leonardo Panegassi

Os artifícios da perfeição: João de Barros por Manuel Severim de Faria

três anos e oito meses. ${ }^{109}$ Todavia, além de tesoureiro, João de Barros ocupou, também, o cargo de feitor da Casa da Índia, tal como observou Manuel Severim de Faria, ao tratar do retorno de João de Barros de sua quinta de Alitém, em Pombal, a Lisboa, oportunidade na qual o rei "o proveu do cargo de Feitor da Casa da India, e Mina (...) cargos (...) de grande cuidado e importância, assim pelo muito que então rendia o comércio de Ásia e África, como por tudo pender da industria do mesmo Feitor que o administrava". ${ }^{110}$ Efetivamente, dom João III o nomeou para o cargo de feitor da Casa da Índia em substituição a Vasco Queimado, no ano de 1533, tal como se pode conferir no excerto abaixo transcrito:

Dom João etc. a quantos esta minha carta virem, faço saber que confiando eu como o ofício de feitor das casas de Guiné e Índias é de tanta substância e fieldade, para o qual é necessário uma pessoa tal e de tanto recado que o saiba e possa bem servir segundo a qualidade do dito ofício requer pela experiência e muita confiança que tenho em João de Barros, que ora serve o dito ofício por meu mandado havendo respeito aos serviços que dele tenho recebido e a boa conta que de si tem dado em todas as coisas de que o encarreguei, e por folgar de lhe fazer mercê o dou ora daqui a diante por feitor das ditas casas de Guiné e Indias, assim e como era Vasco Queimado, que o dito ofício deixou por satisfação que lhe dele dei quando se aposentou. ${ }^{111}$

Entretanto, no contexto do século XVI, o que significava exercer os cargos de tesoureiro do dinheiro da Casa da Índia, de tesoureiro da Casa da Mina, de tesoureiro-mor da Casa de Ceuta e de feitor da Casa da Índia? Para esboçarmos uma resposta a esta questão, vale recuperarmos, em síntese, o papel desempenhado por tais estabelecimentos na história de Portugal e atentarmos para a estrutura de seu funcionamento.

Com efeito, a história dessas instituições liga-se estreitamente e, grosso modo, a Casa da Índia deve ser compreendida como o resultado da evolução sofrida pelos organismos surgidos ao longo do século XV para regular o comércio e a administração do ultramar, ou seja, da Casa de Ceuta - organização criada para atuar em todos os negócios referentes à cidade de Ceuta e fundada, provavelmente, à época da conquista da cidade marroquina - e da Casa da Guiné - organismo fundado em Lagos e, mais tarde, transferido

\footnotetext{
${ }^{109}$ Cf. BAIÃO, António. Introdução. In: op. cit., p. IX, X e XI (cit. à p. XI).

${ }^{110}$ FARIA, Manuel Severim de, op. cit., p. XV.

${ }^{111}$ Nomeação de João de Barros para feitor da Casa da Índia. In: BAIÃO, António (org.). Documentos inéditos sobre João de Barros, sobre o escritor seu homônimo contemporâneo, sobre a família do historiador e sobre os contiuadores das suas "Décadas". Boletim da Segunda Classe da Academia das Sciencias de Lisboa, vol. XL, 1917, p. 204-205. O grifo é meu.
} 
rev. hist. (São Paulo), n. 171, p. 175-212, jul.-dez., 2014 http://dx.doi.org/10.11606/issn.2316-9141.rh.2014.89011
Rubens Leonardo Panegassi

Os artifícios da perfeição: João de Barros por Manuel Severim de Faria

para Lisboa, cuja atuação consistia no comércio português com as feitorias da costa africana, funcionando, simultaneamente, como depósito, tanto dos produtos europeus destinados ao comércio com os africanos, quanto dos produtos da costa da África destinados a Portugal. ${ }^{112}$

A organização dessas instituições veio arrematar uma política econômica da Coroa portuguesa que se propunha a assumir a organização do comércio com o Oriente. Desse modo, a Casa da Índia se tornaria não apenas o centro do comércio, como, também, de toda a administração ultramarina. Da grandiosidade que a instituição veio a adquirir o humanista Damião de Góis nos dá notícias, considerando-a um dos sete grandes edifícios em sua Descrição da cidade de Lisboa, publicada em Évora no ano de 1554. Por sua vez, a notável grandiosidade da instituição registrada pelo humanista em meados do século XVI é um dos resultados de uma política de intervenção do reino português nos negócios da Índia. Com efeito, foi diante da crescente importância que a Casa da Índia adquiriu para o reino que dom Manuel I publicou, em 1509, um regimento por meio do qual se propunha a organizar o funcionamento dessa instituição. Efetivamente, foi com o Regimento das Casas das Índias e Mina que a designação "Casa da Índia" se consagrou. ${ }^{113}$

O regimento divide a instituição em Casa dos escravos, Casa da Guiné e Mina e Casa da Índia, sendo que cada uma dessas seções possuía seu tesoureiro e seu escrivão próprios. Por sua vez, todas estas repartições eram subordinadas a uma autoridade central, o feitor da Casa da Índia, um funcionário de grandes responsabilidades e que só prestava conta de seus atos ao rei. Compunham ainda o grupo de funcionários de alto escalão, os tesoureiros. O regimento determinava a existência de três tesoureiros, a saber, o tesoureiro da Casa da Índia, o tesoureiro da Guiné e Mina e o tesoureiro do dinheiro. A divisão das tarefas entre o tesoureiro da Guiné e Mina e o tesoureiro da Casa da Índia obedecia a um critério por meio do qual o tesoureiro da Guiné e Mina recebia ouro e era responsável pelas mercadorias a serem exportadas, enquanto o tesoureiro da Casa da Índia recebia espe-

${ }^{112}$ Cf. SERRÃO Joel (dir.). Dicionário..., op. cit., s. v. "Ceuta, Casa de”; "Mina, Casa da” e ALBUQUERQUE, Luís de (dir.) E DOMINGUES, Francisco Contente (coord.). Dicionário..., op. cit., s. v. "Índia, Casa da".

${ }^{113}$ Cf. AlBUQUERQUE, Luís de (dir.) E DOMINGUES, Francisco Contente (coord.). Dicionário..., op. cit., s. v. "Índia, Casa da". É possível cf. também LUZ, Francisco Mendes da. Regimento da caza da Índia: manuscrito do século XVII existente no arquivo geral de Simancas. In: Anais: estudos da geografia da expansão portuguesa, vol. VI, tomo II, 1951, p. 9-23; LUZ, Francisco Mendes da. Regimento da caza da Índia: tittulo das cousas comus e geraes aos officiaes da caza. In: Anais: estudos da geografia da expansão portuguesa, vol. VI, tomo II, 1951, p. 27-35. 
ciarias, drogas, pedraria e aljôfar. No que tange ao tesoureiro do dinheiro, ele era responsável pelas vendas e pelos livros de receitas e de despesas da Casa da Índia, em que os escrivães declaravam as operações comerciais, que eram anualmente enviados ao monarca para fiscalização. ${ }^{114}$

António Borges Coelho descreve a Casa da Índia e Mina como uma vasta empresa de importação e exportação situada à beira do Tejo. Segundo o autor, quando as caravelas ou, mais tarde, as naus e os galeões que operacionalizavam o monopólio régio sobre o trato da Guiné, Mina e Índia aportavam no rio, em Lisboa, era função do feitor da Casa convocar o juíz da Guiné e Índia, seus oficiais, o tesoureiro, bem como a guarda, para que se realizasse uma minuciosa revista das embarcações, em busca de mercadorias não declaradas pela tripulação. ${ }^{115}$

Em essência, é preciso tomar conhecimento de que, enquanto tesoureiro e, depois, feitor, João de Barros ocupou os cargos do mais alto escalão nas Casas da Guiné e Mina e da Índia. Importante notar, ainda, que, enquanto feitor da Casa da Índia, só deveria prestar conta de seus atos diretamente ao rei, fato que, mais uma vez, reitera sua proximidade com o monarca - principalmente se nos lembrarmos que ele foi moço de guarda-roupa do príncipe dom João. Contudo, não se pode deixar de observar que todos estes cargos estavam ligados ao comércio e não às armas.

Com efeito, existe uma diferença fundamental entre a milícia e o comércio que nos remete, mais uma vez, à tópica das armas. Diante disso, interessa recuperarmos o que escreveu Baldassare Castiglione a respeito da importância das armas para o cortesão:

(...) considero que a principal e verdadeira profissão do cortesão deve ser das armas; à qual desejo sobretudo que ele se dedique vivamente, e seja conhecido entre os outros como ousado, valoroso e fiel àquele a quem serve. E a fama dessas boas qualidades há de adquirir se delas der provas em todo tempo e lugar, pois não é lícito jamais falhar nisso, sem intensas críticas. ${ }^{116}$

Notemos, portanto, que o exercício da cortesania deveria fazer do uso das armas sua profissão. Por isso, o cortesão deveria ser dotado de bela forma de corpo, ser viril e de boa compleição para que possa demonstrar "força,

\footnotetext{
${ }^{114}$ Cf. ALBUQUERQUE, Luís de (dir.) \& DOMINGUES, Francisco Contente (coord.). Dicionário..., op. cit., s. v. "Índia, Casa da".

${ }^{115}$ Cf. COELHO, António Borges, op. cit., p. 26 e ss.

${ }^{116}$ CASTIGLIONE, Baldassare, conte, op. cit., p. 31/32.
} 
leveza e desenvoltura, e saiba todos os exercícios corporais que são exigidos de um homem de guerra". ${ }^{117}$ Tudo isso para que o cortesão, nobre por natureza, alcance aquilo que lhe deve ser característico, ou seja, superar em glória e fama o legado de seus antepassados, pois lhe seria censurável se não chegasse ao menos no ponto que lhe "foi assinalado por seus ancestrais". ${ }^{118}$

Diogo Ramada Curto chama a atenção para o fato de que a milícia pode ser compreendida como uma forma específica de educação, que começa pela apropriação dos antigos valores cavalheirescos, onde "a honra, o ser, o preço e riqueza de um soldado não consiste no apelido de sua família, na herança de seus avós, na riqueza e morgado de seu pai, nem outros juros, tenças e rendas de que tenha esperança (...) senão na virtude, valor e magnanimidade e esforço próprio". ${ }^{119}$ Vale lembrar, nesse sentido, o que escreveu Duarte Pacheco Pereira a respeito de seus feitos como capitão de São Jorge da Mina, dentre os quais menciona a descoberta de lugares e rios, em face de uma evidente necessidade de sublinhar a superação dos feitos legados por seus ancestrais.

Ora, o verdadeiro cortesão de Castiglione esboça o modelo exemplar do homem de corte e representa, portanto, mais uma aspiração desta sociedade do que, propriamente, uma realização concreta. Portanto, nossa hipótese, aqui, é de que esta deve ser a chave de leitura com a qual devemos compreender a afirmação feita por Manuel Severim de Faria, de que o rei dom João III teria designado João de Barros para capitanear a fortaleza de São Jorge da Mina, uma vez que tal cargo corresponderia à dignidade da nobreza de João de Barros. Sobretudo em vista do fato de que seu texto é concebido, aqui, no âmbito de uma rede dinâmica de relações sociais, em que Severim de Faria assume uma clara posição política na construção da carreira individual do autor a serviço do rei e da República. Ao forjar a memória de João de Barros, "Manuel Severim de Faria posiciona-se em relação à querela acerca da importância das armas e das letras para a conservação e o recrudescimento do império católico". ${ }^{120}$ Destarte, assim como Luís de Vasconcelos em seu diálogo Do sítio de Lisboa, de 1608, o chantre defendeu a residência de Filipe II em Lisboa ao longo de seus Discursos, com o argumento de que a cidade deveria ser a sede da corte do rei católico, pois ela era o verdadeiro centro da monarquia

\footnotetext{
${ }^{117}$ Idem, ibidem, p. 36.

${ }^{118}$ Ibidem, p. 28.

${ }^{119}$ Cf. CURTO, Diogo Ramada, op. cit., p. 114.

${ }^{120}$ ANDRADE, Luiz Cristiano de. Os preceitos da memória: Manuel Severim de Faria, inventor de autoridades lusas. História e Perspectivas nº 34, Uberlândia, jan.jun. 2006, p. 110.
} 
dual, uma vez que, em um domínio fragmentado, o mar seria o elemento de articulação mais evidente, de modo que sua defesa em muito se beneficiaria da presença da armada real no combate aos ataques piratas. ${ }^{121}$

Com efeito, na contextualização da composição deste retrato heróico, não podemos perder de vista o fato de que, após a instituição do regime das capitanias hereditárias, dom João III concedeu a João de Barros, em associação com Fernão de Álvares de Andrade, a capitania do Maranhão, a 11 de fevereiro de 1535. Em certa medida, este fato corresponde à dignidade de João de Barros. Entretanto, é preciso anotar que o Maranhão era um lugar inóspito e ainda pouco conhecido, cujas dificuldades de navegação obstaculizavam o acesso a uma costa "varrida pela rápida corrente de leste-oeste que deturpava o cálculo das distâncias percorridas, por súbitas borrascas tropicais, e pelos perigos de uma orla arenosa e de dunas traiçoeiras". ${ }^{122}$

Era, de fato, uma área de interesse secundário para a Coroa portuguesa até então, uma vez que os interesses portugueses nesse momento estavam centrados, principalmente, no comércio de especiarias e outras mercadorias lucrativas na Índia, bem como na conservação das feitorias e fortalezas espalhadas pelo continente africano, fundamentais para a manutenção e expansão não apenas desse comércio, mas também das ilhas atlânticas. Da importância da Ásia nessa conjuntura em relação à Província de Santa Cruz, basta atentarmos para o fato de que é exatamente a partir de meados do século XVI que se pode detectar um aumento na produção de textos referentes à presença portuguesa no Oriente, quando, além das Décadas de João de Barros, foram publicadas, também, a História do descobrimento e conquista da Índia, de Fernão Lopes de Castanheda e os Comentários de Afonso de Albuquerque, de Brás Afonso de Albuquerque, fenômeno que denota um nítido interesse em divulgar tais feitos por sua grandiosidade. Ainda neste sentido, Diogo Ramada Curto atenta para o fato de que, entre a década de 1570 e os anos de 1620, o Oriente, "nomeadamente os feitos portugueses na Índia, permanece no centro das atenções, enquanto o interesse pelo Brasil conduz às primeiras representações literárias". ${ }^{123}$

\footnotetext{
${ }^{121}$ Cf. BOUZA ÁLVAREZ, Fernando. Lisboa sozinha, quase viúva. A cidade e a mudança da corte no Portugal dos Filipes. Tradução de Nuno Miguel Camarinhas. In: Penélope. Fazer e desfazer a história, $\mathrm{n}^{\mathrm{0}} 13,1994$, p. 71-93.

${ }^{122}$ MOREIRA, Rafael \& THOMAS, William M., op. cit., p. 102.

${ }^{123}$ CURTO, Diogo Ramada, Cultura imperial..., op. cit., p.145.
} 
rev. hist. (São Paulo), n. 171, p. 175-212, jul.-dez., 2014 http://dx.doi.org/10.11606/issn.2316-9141.rh.2014.89011
Rubens Leonardo Panegassi

Os artifícios da perfeição: João de Barros por Manuel Severim de Faria

Com efeito, além da doação da capitania do Maranhão, é possível alinhar, ainda, outros fatos que nos permitem redesenhar, sensivelmente, a figura de João de Barros apresentada por Manuel Severim de Faria. Primeiramente, vale observarmos, mais uma vez, sua formação humanista.

Em Portugal, ao longo do século XVI, este movimento cultural concentrava-se, fundamentalmente, em dois polos, a saber, a corte e a universidade. Por sua vez, de acordo com Américo da Costa Ramalho, convencionou-se fazer coincidir o início do humanismo em Portugal com o ano da chegada do siciliano Cataldo Parisio Sículo, por volta de 1485 - embora caiba a observação: "uma muito pontual e restrita influência itálica detecta-se ainda no tempo de Dom Afonso $\mathrm{V}$, pelos meados do século XV, com a fixação na corte dos eruditos transalpinos Mateus Pisano e Justo Baldino". ${ }^{24}$ Professor de retórica da Universidade de Pádua ao longo de quatro anos, Cataldo Sículo adaptouse perfeitamente à corte portuguesa, segundo Luís de Matos, o que lhe rendeu notoriedade. ${ }^{125}$ Figura emblemática do movimento humanista português ao longo de sua vida - teria falecido em 1517 -, o professor siciliano jamais ensinaria na universidade portuguesa, então em Lisboa, mas teria sido preceptor dos príncipes e dos filhos da alta nobreza lisboeta - teria educado, entre outros, dom Jorge, filho bastardo de dom João II; a infanta dona Joana; dom Pedro de Meneses e sua irmã, dona Leonor de Noronha; dom Dinis, irmão mais novo do duque de Bragança. Todavia, embora tenha sido neste ambiente de corte que João de Barros cresceu e foi educado, tal como vimos, nem a bibliografia consultada, nem as fontes consultadas até o momento fazem qualquer menção de que ele tenha sido aluno de Cataldo Sículo. ${ }^{126}$ Somemos a isso o fato de que Américo da Costa Ramalho sugere que João de Barros teria tomado contato com a cultura renascentista "em parte como autodidata", além de sustentar que o historiador quinhentista foi um fraco helenista. ${ }^{127}$

Desse modo, João de Barros, embora conhecesse bem o latim, não dominava profundamente o grego. Além disso, sua atividade ligada à mercância, e não às armas, é outro elemento que nos permite redimensionar

\footnotetext{
${ }^{124}$ MENDES, António Rosa. A vida cultural. In: MATTOSO, José. (dir.) \& MAGALHÃES, Joaquim R. (coord.). História de Portugal. No alvorecer da modernidade. Lisboa: Editorial Estampa, 1998, p. 333. ${ }^{125} \mathrm{Cf}$. MATOS, Luis de. L'expansion portugaise dans la littérature latine de la Renaissance. Lisboa: Fundação Calouste Gulbenkian, 1991, p. 82 e ss.

${ }^{126}$ Sobre os alunos de Cataldo Sículo cf. RAMALHO, Américo da Costa. Cataldo. In: COLÓQUIO INTERNACIONAL HUMANISMO LATINO NA CULTURA PORTUGUESA - CÁTEDRA HUMANISMO LATINO. Intervenção, 17 a 19 outubro de 2002, p. 1-5.

${ }^{127}$ Cf. RAMALHO, Américo da Costa. João de Barros, humanista. In: Oceanos..., op. cit., p. 68 - 73.
} 
a figura deste humanista. Segundo António Borges Coelho, a nomeação de João de Barros para as funções de tesoureiro da Casa da Mina, tesoureiro da Casa da Índia e tesoureiro-mor de Ceuta "legitima a hipótese da ligação de Barros, por via materna, com os homens de negócio de Lisboa". ${ }^{128}$ Por fim, a observação de Borges Coelho nos coloca diante de um último elemento da "Vida de João de Barros" que nos chama a atenção mais por sua ausência que por sua presença: a figura materna do historiador quinhentista.

Se, como sugeriu Emmanuel Le Roy Ladurie, ${ }^{129}$ havia uma classificação hierárquica das várias figuras de cortesãos fixadas em aspectos distintivos, em que as diferenças entre o bastardo e o legítimo ganhavam sentido e serviam para marcar a posição ocupada pelo cortesão na estrutura social, é possível compreendermos o exercício retórico produzido por Manuel Severim de Faria como um instrumento elaborado para a diluição desta mácula. Seria, então, a "Vida de João de Barros" uma tentativa de escamotear sua condição de bastardo? Sem resposta possível, podemos apenas especular sobre o fato de que a estabilização da figura do autor das Décadas deveria obedecer a um rígido critério de seleção daquilo que o deveria caracterizar diante de uma necessária credibilidade desse personagem e, consequentemente, de sua obra, frente a seus iguais.

\section{Referências bibliográficas}

\section{Fontes}

BAIÃO, António (org.). Documentos inéditos sobre João de Barros, sobre o escritor seu homônimo contemporâneo, sobre a família do historiador e sobre os continuadores das suas "Décadas". Boletim da Segunda Classe da Academia das Sciencias de Lisboa, vol. XL, 1917.

BARROS, João de. Da Ásia de João de Barros. Dos feitos que os portugueses fizeram no descobrimento e conquista dos mares e terras do Oriente, década terceira, parte primeira, livro III, capítulo I. Lisboa: Na Regia Oficina Tipográfica, 1777.

Panegírico do rei dom João III. In: Panegíricos (Panegírico de dom João III e da infanta dona Maria). Texto restituído, prefaciado e notas pelo prof. M. Rodrigues Lapa. Lisboa: Livraria Sá da Costa, 1943.

${ }^{128}$ COELHO, António Borges, op. cit., p. 28.

${ }^{129}$ Cf. LADURIE, Emmanuel Le Roy, op. cit. 
rev. hist. (São Paulo), n. 171, p. 175-212, jul.-dez., 2014 http://dx.doi.org/10.11606/issn.2316-9141.rh.2014.89011
Rubens Leonardo Panegassi

Os artifícios da perfeição: João de Barros por Manuel Severim de Faria

Ropicapnefma, volume II.. Reprodução fac-similada da edição de 1532. Leitura modernizada, notas e estudo de I. S. Révah. Lisboa: Instituto Nacional de Investigação Científica, 1983.

BLUTEAU, Raphael. Vocabulario portuguez, \& latino. Authorizado com exemplos dos melhores escritores portuguezes $\&$ latinos, e offerecido a el rey de Portugal Dom Joam V. pelo padre Dom Raphael Bluteau. Lisboa: Na Officina de Pascoal da Sylva, 1712/1728. Disponível em: http://www.ieb.usp.br/online/index.asp. Acesso em: 09/08/2011.

FARIA, Manuel Severim de. Discursos vários políticos. Editado por Maria Leonor Soares Albergaria Vieira. Lisboa: Imprensa Nacional; Casa da Moeda, 1999.

Discursos varios politicos, por Manoel Severim de Faria chantre E conego na Santa Se de Évora. Évora: impressos por Manoel Carvalho, impressor da Universidade, 1624.

Vida de João de Barros por Manuel Severim de Faria e indice geral das quatro décadas da sua Ásia (1624). Nova edição. Lisboa: Na Régia Officina Typografica, 1777-1788.

LUZ, Francisco Mendes da. Regimento da caza da Índia: manuscrito do século XVII existente no arquivo geral de Simancas. In: Anais: estudos da geografia da expansão portuguesa, vol. VI, tomo II, 1951, p. 9- 23.

Regimento da caza da Índia: tittulo das cousas comus e geraes aos officiaes da caza. In: Anais: estudos da geografia da expansão portuguesa, vol. VI, tomo II, 1951, p. 27-35.

PEREIRA, Duarte Pacheco. Esmeraldo de situ orbis. In: CARVALHO, Joaquim Barradas de. Esmeraldo de situ orbis de Duarte Pacheco Pereira. Edição crítica e comentanda. Lisboa: Fundação Calouste Gulbenkian/Serviço de Educação, 1991.

QUINTO HORÁCIO FLACO. Arte poética, linhas 309-318. Tradução de Mauri Furlan. Disponível em: http://www.latim.ufsc.br/986ED7F3-3F3A-4BC2-BBE3-A3514D872AC1.html. Acesso em: 05/08/2011.

\section{Bibliografia}

ALBUQUERQUE, Luís de (dir.) \& DOMINGUES, Francisco Contente (coord.). Dicionário de história dos descobrimentos portugueses. Lisboa: Caminho, 1994.

ALMEIDA, Isabel. Aulegrafia: "rascunho da vida cortesã", "largo discurso da cortesania vulgar". In: Península. Revista de Estudos Ibéricos, nº 2, 2005, p. 201-218.

AMARAL, Sérgio Alcides Pereira do. Desavenças. Poesia, poder e melancolia nas obras do doutor Francisco de Sá de Miranda. Tese de doutorado, História, FFLCH-USP, 2007.

ANDERSON, Perry. Linhagens do Estado absolutista. Tradução de João Roberto Martins Filho. São Paulo: Brasiliense, 2004.

ANDRADE, António Alberto Banha de. João de Barros: historiador do pensamento humanista português de Quinhentos. Lisboa: Academia Portuguesa da História, 1980.

ANDRADE, Luiz Cristiano de. Os preceitos da memória:ManuelSeverim deFaria, inventor de autoridades lusas. História e Perspectivas, nº 34, Uberlândia, jan./jun. 2006, p. 107-137.

BAIÃO, António. Introdução. In: BARROS, João de. Ásia de Joam de Barros. Dos feitos que os portugueses fizeram no descobrimento e conquista dos mares e terras do Oriente. Quarta 
rev. hist. (São Paulo), n. 171, p. 175-212, jul.-dez., 2014 http://dx.doi.org/10.11606/issn.2316-9141.rh.2014.89011
Rubens Leonardo Panegassi

Os artifícios da perfeição: João de Barros por Manuel Severim de Faria

edição revista e prefaciada por António Baião. Coimbra: Imprensa da Universidade, 1932 (Edição fac-similar Lisboa: Imprensa Nacional-Casa da Moeda, 1998).

BENNASSAR, Bartolomé. La España del siglo de oro. Tradução de Pablo Bordonaba. Barcelona: Crítica, 2010.

BOUZA ÁLVAREZ, Fernando. Escribir en la corte. La cultura de la nobleza cortesana y las formas de comunicación en el siglo de oro. In: ZUGASTI, Miguel \& MATA, Carlos (ed.). In: CONGRESO EL SIGLO DE ORO EN EL NUEVO MILÊNIO. Actas, tomo II. Barañáin (Navarra): Eunsa, 2005, p. 77-99.

Lisboa sozinha, quase viúva. A cidade e a mudança da corte no Portugal dos Filipes. Tradução de Nuno Miguel Camarinhas. In: Penélope. Fazer e desfazer a história, $\mathrm{n}^{\circ} 13,1994$, p. 71-93.

. Portugal no tempo dos Filipes. Política, cultura, representações (1580-1668). Tradução de Ângela Barreto Xavier e Pedro Cardim. Edições Cosmos, 2000.

BOXER, Charles R. João de Barros, Portuguese humanist and historian of Asia. Nova Delhi: Concept Publishing Company, 1981.

. O império marítimo português, 1415 - 1825. Tradução de Anna Olga de Barros Barreto. São Paulo: Companhia das Letras, 2002.

BURKE, Peter. O cortesão. In: GARIN, Eugenio. O homem renascentista. Tradução de Maria Jorge Vilar de Figueiredo. Lisboa: Editorial Presença, 1991.

CARVAlHO, Maria do Socorro Fernandes de. Poesia de agudeza em Portugal. São Paulo: Humanitas Editorial; Edusp; Fapesp, 2007.

CERTEAU, Michel de. A escrita da história. Tradução de Maria de Lourdes Menezes; revisão técnica de Arno Vogel. Rio de Janeiro: Forense Universitária, 2000.

CHABOD, Federico. Escritos sobre el Renacimiento. Tradução de Rodrigo Ruza. México: FCE, 1990.

CHAUnU, Pierre. A civilização da Europa clássica, vol. I. Tradução de Teresa F. Rodrigues. Lisboa: Editorial Estampa, 1985.

COELHO, António Borges. João de Barros: vida e obra. Lisboa: Grupo de Trabalho do Min. da Educação para as Comemorações dos Descobrimentos Portugueses, 1997. Tudo é mercadoria. Sobre o percurso e obra de João de Barros. Lisboa: Caminho, 1992.

CURTO, Diogo Ramada. A cultura política. In: MATTOSO, José (dir.). História de Portugal, $3^{\circ}$ volume: No alvorecer da modernidade. Lisboa: Editorial Estampa, 1997. Cultura imperial e projetos coloniais (séc. XV a XVIII). Campinas/SP: Editora da Unicamp, 2009.

O discurso político em Portugal (1600-1650). Lisboa: Projecto Universidade Aberta, 1988.

ELIAS, Norbert. A sociedade de corte: investigação sobre a sociologia da realeza e da aristocracia de corte. Tradução de Pedro Sussekind. Rio de Janeiro: Zahar, 2001.

FRANÇA, Eduardo d'Oliveira. Portugal na época da Restauração. São Paulo: Editora Hucitec, 1997.

GARIN, Eugenio. La cultura del Rinascimento. Milão, 1988. 
rev. hist. (São Paulo), n. 171, p. 175-212, jul.-dez., 2014 http://dx.doi.org/10.11606/issn.2316-9141.rh.2014.89011
Rubens Leonardo Panegassi

Os artifícios da perfeição: João de Barros por Manuel Severim de Faria

HESPANHA, António Manuel. Imbecillitas. As bem-aventuranças da inferioridade nas sociedades de Antigo Regime. São Paulo: Annablume, 2010.

LADURIE, Emmanuel Le Roy. O Estado monárquico, França, 1460-1610. Tradução de Maria Lúcia Machado. São Paulo: Companhia das Letras, 1994.

LE GOFF, Jaques. História e memória. Tradução de Bernardo Leitão et alii. Campinas, SP: Editora da Unicamp, 2003.

LIMA, Luiz Costa. O redemunho do horror: as margens do Ocidente. São Paulo: Editora Planeta do Brasil, 2003.

MAGALHÃES, Joaquim Romero. As estruturas políticas de unificação: o rei. In: MATTOSO, José (dir.). História de Portugal, $3^{\circ}$ volume: No alvorecer da modernidade. Lisboa: Editorial Estampa, 1997.

MARAVALL, José Antonio. Antiguos y modernos. Visión de la historia e idea de progreso hasta el Renacimiento. Madri: Alianza Editorial, 1986.

MATOS, Luis de. L'expansion portugaise dans la littérature latine de la Renaissance. Lisboa: Fundação Calouste Gulbenkian, 1991.

MEGIANI, Ana Paula Torres. Contar coisas de todas as partes do mundo: as Relaciones de Sucesos e a circulação de notícias escritas no período filipino. In: ALMEIDA, Suely Creusa Cordeiro de et alii (org.). Cultura e sociabilidades no mundo atlântico. Recife: Ed. Universitária da UFPE, 2012, p. 469-483.

O rei ausente: festa e cultura política nas visitas dos Filipes a Portugal (1581 a 1619). São Paulo: Alameda, 2004.

Política e letras no tempo dos Filipes: o Império português e as conexões de Manoel Severim de Faria e Luís Mendes de Vasconcelos. In: BICALHO, Maria Fernanda \& FERLINI, Vera Lúcia Amaral. Modos de governar: ideias e práticas políticas no Império português. Séculos XVI-XIX. São Paulo: Alameda, 2005.

MENDES, António Rosa. A vida cultural. In: MATTOSO, José (dir.) E MAGALHÃES, Joaquim R. (coord.). História de Portugal. No alvorecer da modernidade. Lisboa: Editorial Estampa, 1998.

MONTEIRO, Rodrigo Bentes. O rei no espelho. A monarquia portuguesa e a colonização da América, 1640-1720. São Paulo: Hucitec, 2002.

MOREIRA, Rafael $\&$ THOMAS, William M. Desventuras de João de Barros primeiro colonizador do Maranhão - O achado da nau de Aires da Cunha naufragada em 1536. In: Oceanos. João de Barros e o cosmopolitismo do Renascimento, $\mathrm{n}^{\circ}$ 27. Lisboa: Comissão Nacional para a Comemoração dos Descobrimentos Portugueses, julho/setembro 1996, p. 101-111.

OLIVEIRA, Maria Lêda. A história do Brazil de frei Vicente do Salvador: história e política no Império português do século XVII. Rio de Janeiro: Versal; São Paulo: Oderbrecht, 2008.

PÉCORA, Alcir. Prefácio à edição brasileira. A cena da perfeição. In: CASTIGLIONE, Baldassare, conte. $O$ cortesão. Tradução de Carlos Nilson Moulin Louzada. São Paulo: Martins Fontes, 1997. 
RAMALHO, Américo da Costa. Cataldo. In: COLÓQUIO INTERNACIONAL HUMANISMO LATINO NA CULTURA PORTUGUESA - CÁTEDRA HUMANISMO LATINO. Intervenção, 17 a 19 outubro de 2002, p. 1-5.

João de Barros, humanista. In: Oceanos. João de Barros e o cosmopolitismo do Renascimento, $\mathrm{n}^{0}$ 27. Lisboa: Comissão Nacional para a Comemoração dos Descobrimentos Portugueses, julho/setembro 1996, p. 68-73.

RAMINELLI, Ronald. Viagens ultramarinas: monarcas, vassalos e governo a distância. São Paulo: Alameda, 2008.

REBELO, Luis de Sousa. A tradição clássica na literatura portuguesa. Lisboa: Livros Horizonte, 1982.

ROSSI, Paolo. O passado, a memória, o esquecimento. Seis ensaios da história das ideias. Tradução de Nilson Moulin. São Paulo: Editora Unesp, 2010.

SARAIVA, António José \& LOPES, Óscar. História da literatura portuguesa. Porto: Porto Editora, 2008.

SARAIVA, António José. Uma concepção planetária de história em João de Barros. In: Para a história da cultura em Portugal, volume II. Lisboa: Publicações Europa-América, 1972.

SERRÃO Joel (dir.). Dicionário de história de Portugal. Castanhoso/Fez. Porto: Livraria Figueirinhas, 1992.

SILVA, Innocencio Francisco da. Diccionario bibliographico portuguez. Lisboa: Imprensa Nacional, 1862.

SKINNER, Quentin. Motives, intentions and the interpretation of texts. In: New Literary History, vol. 3, n 2, On Interpretation: I, Winter, 1972, p. 393-408.

SLOANE, Thomas O (editor in chief). Encyclopedia of rhetoric. Oxford: Oxford University Press, 2001.

THOMPSON, I. A. A. El contexto institucional de la aparición del ministro-favorito. In: ELLIOTT, John \& BROCKLISS, Laurence (dir.). El mundo de los validos. Tradução de Jesús Alborés e Eva Rodríguez Halfter. Madri: Taurus, 2000.

VILARDAGA, José Carlos. São Paulo na órbita do Império dos Felipes: conexões castelhanas de uma vila da América portuguesa durante a União Ibérica (1580-1640). Tese de doutorado, FFLCH/USP. São Paulo, 2010. 